\title{
Cancer-Associated Angiogenesis: The Endothelial Cell as a Checkpoint for Immunological Patrolling
}

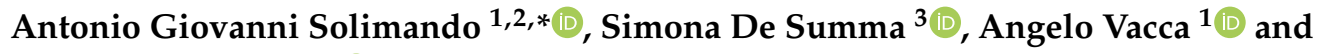 \\ Domenico Ribatti ${ }^{4, *}$ (I) \\ 1 Department of Biomedical Sciences and Human Oncology, Section of Internal Medicine 'G. Baccelli', \\ University of Bari Medical School, 70124 Bari, Italy; angelo.vacca@uniba.it \\ 2 Istituto di Ricovero e Cura a Carattere Scientifico-IRCCS Istituto Tumori "Giovanni Paolo II" of Bari, \\ 70124 Bari, Italy \\ 3 Molecular Diagnostics and Pharmacogenetics Unit, IRCCS Istituto Tumori Giovanni Paolo II, \\ 70124 Bari, Italy; desumma.simona@gmail.com \\ 4 Department of Basic Medical Sciences, Neurosciences, and Sensory Organs, \\ University of Bari Medical School, 70124 Bari, Italy \\ * Correspondence: antonio.solimando@uniba.it (A.G.S.); domenico.ribatti@uniba.it (D.R.); \\ Tel.: +39-3395626475 (A.G.S.); +39-080-5478326 (D.R.)
}

Received: 25 October 2020; Accepted: 12 November 2020; Published: 15 November 2020

Simple Summary: A clinical decision and study design investigating the level and extent of angiogenesis modulation aimed at vascular normalization without rendering tissues hypoxic is key and represents an unmet medical need. Specifically, determining the active concentration and optimal times of the administration of antiangiogenetic drugs is crucial to inhibit the growth of any microscopic residual tumor after surgical resection and in the pre-malignant and smolder neoplastic state. This review uncovers the pre-clinical translational insights crucial to overcome the caveats faced so far while employing anti-angiogenesis. This literature revision also explores how abnormalities in the tumor endothelium harm the crosstalk with an effective immune cell response, envisioning a novel combination with other anti-cancer drugs and immunomodulatory agents. These insights hold vast potential to both repress tumorigenesis and unleash an effective immune response.

\begin{abstract}
Cancer-associated neo vessels' formation acts as a gatekeeper that orchestrates the entrance and egress of patrolling immune cells within the tumor milieu. This is achieved, in part, via the directed chemokines' expression and cell adhesion molecules on the endothelial cell surface that attract and retain circulating leukocytes. The crosstalk between adaptive immune cells and the cancer endothelium is thus essential for tumor immune surveillance and the success of immune-based therapies that harness immune cells to kill tumor cells. This review will focus on the biology of the endothelium and will explore the vascular-specific molecular mediators that control the recruitment, retention, and trafficking of immune cells that are essential for effective antitumor immunity. The literature revision will also explore how abnormalities in the tumor endothelium impair crosstalk with adaptive immune cells and how targeting these abnormalities can improve the success of immune-based therapies for different malignancies, with a particular focus on the paradigmatic example represented by multiple myeloma. We also generated and provide two original bio-informatic analyses, in order to sketch the physiopathology underlying the endothelial-neoplastic interactions in an easier manner, feeding into a vicious cycle propagating disease progression and highlighting novel pathways that might be exploited therapeutically.
\end{abstract}

Keywords: tumor angiogenesis; endothelium; microenvironment; multiple myeloma; immunotherapy; anti-angiogenesis; adhesion molecules; immune-checkpoint inhibitor 


\section{Introduction}

The interface between malignant cells and neighboring vessels, both recently sprouted during angiogenesis, or resident ones, is one of the pivotal physiological events tangled in the expansion of neoplastic cells and their dissemination [1]. Cancer vessels' formation is deemed as the result of an angiogenic switch driven by both genetic and epigenetic mechanisms that hijack the tumor trajectory through a full blown self-sustaining entity able to interact with the surrounding niche [2]. The newly formed tumor blood vessels have specific characteristics that allow discrimination from resting blood vessels [3]. They are characterized by rapid proliferation, increased permeability, and disorganized architecture [4]. Initially thought to be a must for the growth and progression of tumors, the formation of new vessels was regarded as one of the hallmarks of both solid $[5,6]$ and hematological malignancies [7-9]. However, this has turned out not to be the case, as tumors have been uncovered to also be able to grow without neo-angiogenesis, mainly by co-opting pre-existing vessels, but also through vascular mimicry [10]. Since its discovery by Dr. Judah Folkman, tumor angiogenesis has been proposed as a target for novel tumor therapies [11]. However, the success in the clinic of anti-angiogenic compounds has been limited in contrast to many preclinical positive results obtained in animal models [12]. This is partly determined by heterogeneous vascular and immunological pattern dependencies fueling the boundary between the cancer cells and the endothelium counterpart $[13,14]$.

Solid tumor is made up of a plethora of cell types rather than just a homogeneous mass of cancer cell, such as cancer associated fibroblasts, an heterogenous immune cell infiltrate, and the individual cells that form the blood and lymphatic vessels [15]. The biology of the individual cells that form the tumor vasculature is central to many processes in the tumor microenvironment, providing oxygen and nutrients, forming conduits for metastases, and directly signaling into nearby cancer cells or other stromal cells $[16,17]$. The niche is also important during the crosstalk with immune cells and the endothelium has been uncovered to be a gatekeeper, representing the first cell type that immune cells contact as they are exiting the circulation into the tumor, but also as they leave the tumor back into circulation [18]. The endothelial cells can thus act as a director in many ways in this process of tumor immune surveillance by its ability to interact directly with immune cells and malignant cells.

The ability to develop an angiogenetic response is a property common to all tissues. Tumor angiogenesis has historically been uncovered to be one of the key hallmarks of cancer [19]. Nonetheless, one of the main problems in comparing the different clinical studies that have used antiangiogenetic therapies is the lack of reliable markers for the assessment of the antiangiogenetic activity and efficacy of the drugs used [20]. Moreover, a tumor response to these drugs, in the form of reduction of tumor mass alone, may not be an appropriate index of the effectiveness of the treatment, owing to the cytostatic nature of the treatment and the potential contribution of the vasculature in promoting tumor immunosuppression [21]. This seems to be related to the chaotic and disorganized nature of the tumor vasculature, but also to a plethora of ancillary mechanisms [22]. Furthermore, the ability of an antiangiogenetic drug to induce a prolonged stabilization of the disease and an increase in survival should be considered more significant in the assessment of the response to antiangiogenetic therapies [23]. Here, we recapitulate the available data from a translational standpoint and support the picture we draw of the pathophysiological dysregulated endothelial-neoplastic interactions with two bio-informatic interrogations that show, on the one hand, a vicious cycle of disease progression and, on the other hand, pinpoint pathways of potential therapeutic interest.

\section{Antitumor Immunity Impairment: Role of Structural and Functional Abnormalities}

Despite its essential role, tumor vasculature is structurally and functionally aberrant, with intercellular junctions and extracellular matrix attachments may not form normally in tumors, leading to impaired monolayer formation and barrier function. Completely chaotic loss of tight junctions between adjacent individual cells in the overlapping endothelium, with odd sprouts being cast across the lumen of tumour vasculature, would be an impediment to proper tumor immune surveillance. These abnormalities also occur at the levels of the vasculature in the individual cells directly interacting 
with the extracellular matrix (ECM) and the pericytes that typically wrap around the outside of the vessel, providing support and stability; nonetheless, in the tumor microenvironment, pericytes are sparse and they are loosely attached to the surface of the tumour vessels, directly contributing to some of the vascular dysfunction [24]. Consistent with preclinical models, patient tumour vessels are disorganized and half of the vessels do not seem to support blood flow at all; alternatively, blood could be detected pooling and flowing in the opposite direction and the vessel diameters have been uncovered to be atypical; a lower wall shear stress can influence the delivery of drugs and immunotherapy along with impaired cancer immune surveillance due to disorganization in the tumor vessels [25]. Thus, there are many aspects of the cancer niche that make it inhospitable to infiltrating immune cells, thus inspiring several strategies aimed to target different aspects of the tumor microenvironment with the goal of improving both the quantity and the quality of infiltrating immune cells [21]. Defining tumors based on the quantity and the quality of immune cell infiltrates allowed to dissect cancer milieu with abundant immune cells, namely inflamed and cold malignancies, as well as immune cells able to enter the tumor microenvironment despite being suppressed [26]. The cancer endothelium can thus be considered a gatekeeper for leukocyte entry and egress from solid and hematological cancers, triggering a cascade that implicates the leukocyte capture by the vessel wall as well as their rolling along the activated surface, and eventually immune cells arrest; next, in order to spread, the patrolling leukocytes ultimately pass through the endothelial boundary via paracellular routes between two adjacent endothelial cells, also being prone to infiltrate via transcellular route, directly through the endothelial cells cytoplasm [27]. Chemokines and integrins play a pivotal role in extracellular matrix (ECM) degradation. In more detail, integrins as heterodimeric molecules constituted by alpha and beta subunits on the cell surface bind to microenvironmental structures via fibronectin and laminin, while activating degradation pathways such as matrix-metallo-proteinases (MMPs) and urokinase-type plasminogen activator (uPA) [28,29]. Moreover, cell-to-cell and cell-ECM interactions are also mediated by adhesion molecules in both solid [30] and hematological malignancies [31,32]. Modifications in adhesion molecules have been related to invasiveness [33,34], angiogenesis [35,36], and druggable targeting [37-39]. Furthermore, the tumor vasculature restricts the infiltration of adaptive immune cells [40,41]. Thus, modifying the tumor vasculature can result in improved immune therapeutic outcome [42]. Consequently, a modern technique such as single cell RNA sequencing has been used to identify diverse subpopulations of tumor-associated endothelial cells [43]. It is conceivable to envision gene expression patterns and individual cells found throughout solid and hematological malignancies and a high grade of modulation in genes implicated in homing, trafficking, and retention of anti-tumor immune cells, corroborating at single-cell level that tumor cells are actively suppressing those pathways important for anti-tumor immunity $[43,44]$.

\section{Improving Immune-Vascular Crosstalk for Cancer Immunotherapy}

The cancer immunotherapy has revolutionized the way we treat neoplastic patients in the last years. Since the first Food and Drug Administration (FDA) and European Medicines Agency (EMA) approval of the immune checkpoint inhibitor (ICI) ipilimumab for melanoma, which targets the anti CTLA-4 checkpoint, an explosion of approval of different ICIs that target a PD1 or programmed death-ligand 1 (PDL1) for a wide range of cancer indications has been observed [45,46]. The ICIs have provided significant clinical benefit including improvement in overall survival for some of the most aggressive and often lethal cancers [47]; however, despite the promising results, the overall objective response rate gained by ICIs as a monotherapy remains suboptimal, ranging between 20 to $30 \%$, and overall survival and toxicity profile still need to be improved [48-50]. One strategy applied to accomplish higher clinical response is to generate more effective antitumor shrinkage by combining multiple checkpoints [51]. Nonetheless, the toxicity profile is higher [49,52]. Therefore, there is a growing interest aimed to identify alternative strategies to improve the clinical outcome and antitumor response of ICIs, without significantly increasing the risk of toxicities. In the frame of this thinking, cancer immunotherapy points towards a multifaceted profiling and, given the basic pathophysiology 
underlying cancer immune surveillance evasion modalities, multiple strategies, besides ICIs-based ones, are aimed at targeting immunosuppressant metabolites [53]. The T cells can shape tumor blood vessels and cancer endothelium and prevent the recruitment and infiltration of the effector immune cells while remodeling the ECM, further inhibiting the migration and infiltration of functional patrolling immune cells [54]. Tumor vasculature actively contributes to the immune suppression, as tumor vessels are highly abnormal and functionally impaired, determining a significant degree of hypoxia, acidosis, and necrosis within the tumor [55]. These pathophysiological mechanisms can lead to the production of immunosuppressive molecules such as small ions, lactate, and reactive oxygen species, all of which work to suppress effective $\mathrm{T}$ cytotoxic cell function; at the same time, the production of chemokines and cytokines fosters the differentiation and the activation of immunosuppressive cells such as myeloid derived stem cells (MDSCs) and M2, like tumor macrophages, that also act to inhibit the activities of cytotoxic T cells [56]. Conversely, on the vessel, these mechanisms also downregulate multiple adhesion molecules that are essential for the rolling, adhesion, and transmigration of T cells to enter the cancer milieu [57-59], creating a highly immunosuppressive microenvironment, dominated by immune suppressive signals and largely devoid effector T cells. Contrariwise, normalizing tumor vasculature improves $\mathrm{T}$ cell infiltration, boosting the immune reaction and halting the immune suppressing environment to a more immune activating phenotype and working in synergy with the cancer immunotherapy.

Anti-vascular endothelial growth factor receptor (anti-VEGFR) pioneered the attempts to normalize tumor vasculature and restore its function, as indicated by tissue perfusion and decreasing intratumoral hypoxia, and fostered further investigations aimed at shaping the intratumoral immune cell phenotype in parallel with vascular normalization [23], while polarizing macrophages throughout and M1 gene-expression phenotype, paralleling an increase in adaptive immune cells' infiltration in the setting of this antiangiogenic treatment $[23,60]$. Vascular endothelial growth factor (VEGF) and inflammatory molecules are not merely key proangiogenic elements, but are also immune modulators, which boost vascular formation and cooperate in creating permissive environment in most lethal malignancies, and lead to poor drug response [61-63] and survival [19,64]. Remarkably, evidence obtained from pre-clinical and clinical breast cancer models points toward a link between favorable prognostic-related angiogenesis genes and $\mathrm{T}$ cell signaling, effective immune cell infiltration that is also pericyte-dependent [65]. In more detail, pericytes seem to be crucial for recruiting immune cells into the tumor niche and orchestrating an immune-vascular crosstalk involving CD4/CD8 T cells and pericytes. Furthermore, to efficiently unleash immune effector cells, Tian et al. uncovered tumor vascular normalization synergism and ICIs (either anti-PD1 or anti-CTLA4 antibodies) to be operative and parallel CD4 T cell activation [65]. Collectively, the interplay between T cells and tumor vasculature primes a CD4 $\mathrm{T}$ cell activation and the interferon gamma (IFN $\gamma$ ) production, associated with the normalization of tumor vessels and consequent hypoxia attenuation, reduced intra tumor immunoparesis and further recruitment of bystanders' immune infiltrates, leading to an even enhanced angiogenesis homeostasis. Contrariwise, pericytes or CD4 T cells elimination and major histocompatibility complex (MHC)II inactivation boosted cancer hypoxia, immunosuppression, and metastatic potential [54,65]. Compelling additional evidence corroborated the existence of close interactions between the tumor endothelium and immune effectors cells with therapeutic implications for ICIs treatment in a colorectal cancer model in an interferon gamma (IFN $\gamma$ )-dependent fashion [66]. In the frame of this thinking, Zheng et al. highlight the importance of IFN $\gamma$ receptor signaling in host cell populations for both immune response and vascular tumor homeostasis. Thus, a boosting feedback loop of immune reprogramming and tumor vascular regularization shapes the immunoparetic cancer, frequently rich in immunosuppressive cells and dysfunctional effector T lymphocytes being potentially druggable by ICIs, which can in turn stimulate the regularization of blood vessels and ultimately facilitate the infiltration of effector $\mathrm{T}$ cells and improve their function, further halting the immune permissive cancer niche [56]. 


\section{Multiple Myeloma (MM) as a Paradigm for Endothelial Gatekeeper Function within the Neoplastic Niche: In Silico Functional Enrichment Study Identifies Prognostic Relevant Gene Profiles in MM Bone Marrow Derived Endothelial Cells}

Numerous cell types can be mobilized from the bone marrow and directed to the sites of new vessel formation, where they strengthen the proangiogenic effects [1]. Among them, there are non-hematopoietic bone marrow populations, CD45-, called endothelial progenitor cells (EPCs) [67]. Unlike perivascular cells, which function with paracrine mechanisms by secreting VEGF, endothelial progenitors are incorporated into the wall of nascent vessels, where they differentiate into mature endothelial cells. Being VEGFR-1 positive, they bind VEGF and other proangiogenic factors produced by cancer cells [68]. EPCs facilitate vasculogenesis and are deemed a novel target, particularly at the pre-malignant phase of neoplastic process and in the smoldering stage of disease, fostering the "angiogenic switch". Moreover, during neoplastic dissemination, EPCs stimulate the shift from subclinical to macroscopic secondary lesions [69]. Hematological cancers represent a paradigmatic condition in which EPCs-mediated priming of cancer angiogenesis takes place, given the close cross talk with the neoplastic clone, and the putative shared ontogeny. Thus, the description of neoplastic-infiltrating EPCs in hematological malignancies may shed more light on a more precise anti-angiogenic strategy, with the advantage of tipping the balance of critical phases of disease progression [70]. Multiple myeloma represents a poster child condition in this regard, being characterized by a multistep natural history, as well as by variable pre-neoplastic stages preceding full-blown disease [70,71].

Multiple myeloma (MM) is a clonal proliferation of malignant plasma cells (PCs) accumulating and disseminating in the bone marrow (BM) with ensuing induction of focal skeletal lesions and osteoporosis driving myeloma bone disease, anemia, renal insufficiency, hypercalcemia [72], higher infection rates [73-75], and secondary life-threatening complications [76-78]. MM represents an ideal model of colonization and interaction of tumor cells in the bone microenvironment [79-81], where the immune-milieu [82,83] and aberrant angiogenesis shape a permissive ecosystem, supporting disease progression via a plethora of autocrine [84,85] and paracrine loops [86,87].

Recently, we demonstrated that bone marrow endothelial cells from both newly diagnosed (NDMM) and relapsed-refractory multiple myeloma (RRMM) patients feed into a vicious cycle orchestrated by aberrant adhesion molecules on the bone marrow endothelial cells and plasma cell surface and correlate with poor clinical prognosis [31,35,88]. Based on this evidence and several pieces of data [89,90], increased adhesion molecules levels have been uncovered to contribute to more aggressive phenotype $[29,91]$. Direct contact of endothelial cells and endothelial progenitors with MM plasma cells would enhance adhesion molecules levels [92,93]. In silico analysis has been performed on dataset GSE28331 (https://www.ncbi.nlm.nih.gov/geo/query/acc.cgi?acc=GSE28331) [93]. Raw data were RMA normalized, using "affy" package (1.56.0) [94]. The method limma [95] was used to detect differentially expressed genes. The results were considered as statistically significant when adjusted p-value $<0.05$. K-means and hierarchical clustering were executed using "Factoextra" (1.0.5) [96], "dendextend" (1.9.0) [97], "colorspace" (1.3-2) [98], and "ggplot2" (2.2.1) [99].

To characterize the adhesion molecules-related angiogenic switch in more detail and to corroborate available at gene-expression level in a broader spectrum of disease phenotype, we interrogated different independent public datasets. Given that mobilization of endothelial precursors cells (EPCs) occurs at the early stages of MM progression [70], preceding MM progression, we selected the GSE28331 data collection.

Next, determining whether MM EPCs could be distinguished from MM-cells according to the natural grouping of their gene expression profiles, we analyzed publically available data from 20 EPC and 12 MM-cell samples (GSE28331). The analyses clearly split the MM-cells and EPCs into two branches (heatmap, Figure 1A), according to the expression values of the top 100 different regulated genes. Over-expression of angiogenic genes in EPCs deemed statistically significant and relevant for pro-angiogenic biological processes increased expression of angiogenic genes in EPCs deemed 
statistically significant and relevant for pro-angiogenic biological processes (Figure 1A,B). Based on these different expression patterns, we performed an enrichment pathway and functional annotation analysis (Figure 1B). These in silico unpublished data together with the previously described autocrine loop pinpoint that the cell adhesion molecules have noteworthy qualities; they can be involved in the homophilic network on two opposing cell types; moreover, adhesion molecules are shed as soluble isoforms being able to bind to cell-bound isoforms, which in turn even enhances its binding capacity (Figure 2). What develops is a vicious cycle of neoplastic MM cells expressing and shedding adhesion molecules, increasing membrane-bound expression on the endothelium and boosting angiogenesis. In turn, increasing numbers of activated vessels can increasingly bind cancer cells, which promptly catch enhanced space within the neoplastic milieu for contact-mediated interactions $[35,100]$ (Figure 2).

A

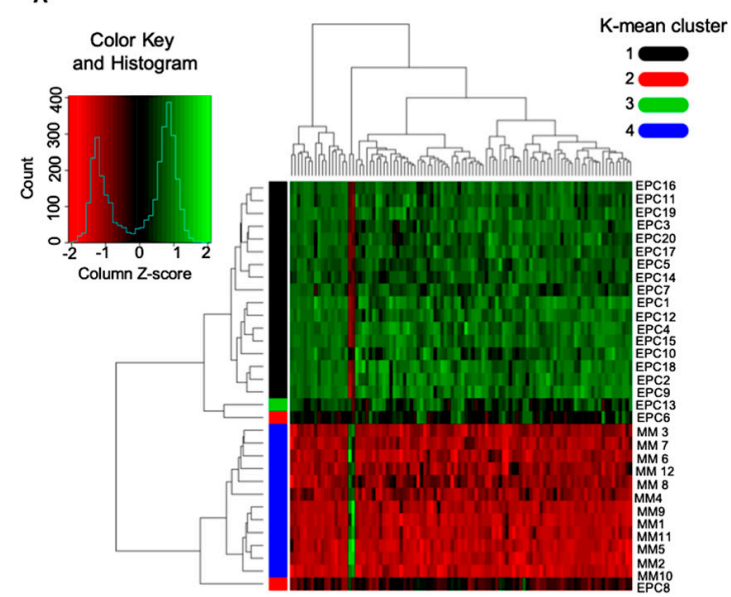

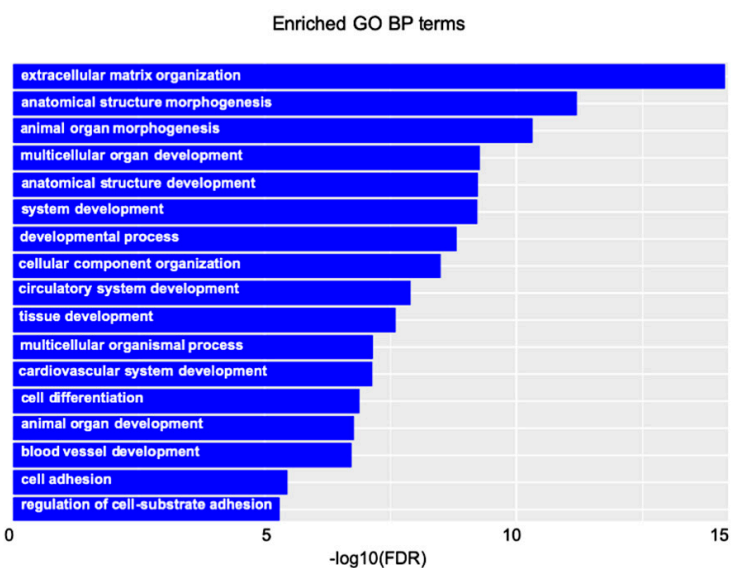

Figure 1. In silico data interrogation points towards a significant crosstalk between the neoplastic-cells and the vasculature counterpart: adhesion-system boosts multiple myeloma (MM)-related angiogenesis in the bone marrow microenvironment. (A) Heatmap, showing expression value of the top 100 deregulated genes, includes a dendrogram with two major branches; one containing MM-cells and one EPC sample, and the other grouping the leftover EPCs. (B) GO functional enrichment results showed that genes are involved in several biological processes. Cell adhesion and angiogenesis were significantly enriched in the gene network analysis. EPCs: endothelial precursor; GO: gene ontology; BP: biological process.

The K-means clustering from the above-mentioned GSE28331 dataset (Figure 3A) showed highly ranked enriched biological processes including blood vessel formation, cell adhesion, and developmental processes; the network analysis highlighted a significant enrichment for focal adhesion and matrix-receptor interaction Kyoto Encyclopedia of Genes and Genomes (KEGG) pathways (Figure 3B).

Consequently, using several pre-clinical models [30,88,102], blocking the adhesion system seems to halt blood vessel formation, reduce adhesion-mediated networks, and weaken neoplastic disease progression. These therapeutic effects of interfering with the adhesion system were observed in translational animal models, not in patients and, therefore, must be interpreted with caution. Nevertheless, these pieces of evidence may be a warning of a pivotal druggable targets of $\mathrm{MM}$ and, more generally, microenvironment addicted malignancies that might be investigated therapeutically.

The dysregulated endothelial-neoplastic interactions sketched by our bio-informatic investigations show, on the one hand, a vicious cycle of disease progression and, on the other hand, point out pathways of potential therapeutic interest. These gene expression profiles were observed in one model of disease, and thus must be interpreted with caution and need further validation on a broad spectrum of malignancies. Nonetheless, solid and hematological malignancies share common mechanisms involving the cross talk between the cancer endothelium and the immune microenvironment, as summarized in Table 1. 


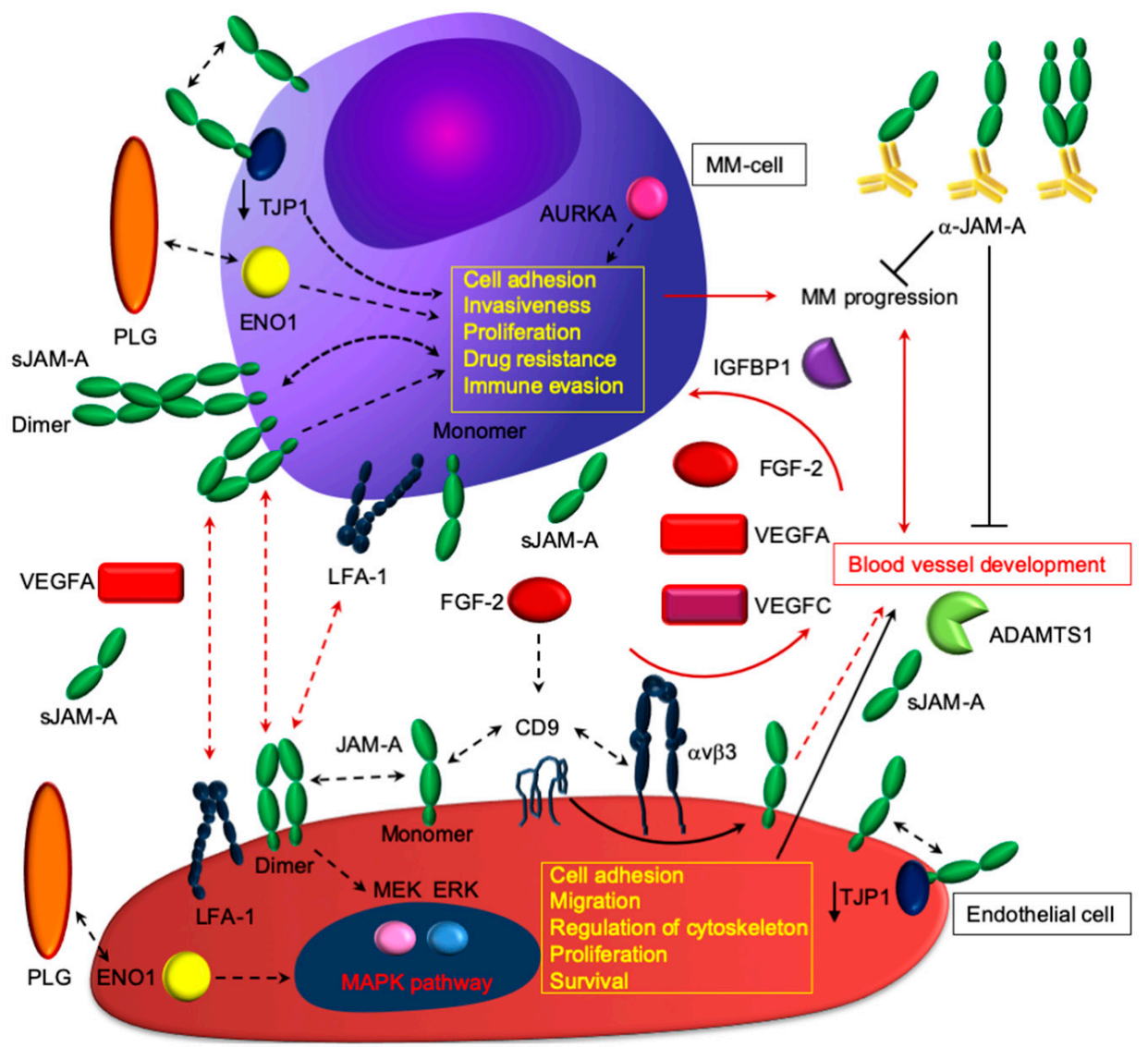

Figure 2. Proposed paradigmatic model of how junctional adhesion molecule-A (JAM-A) plays a pivotal role in angiogenesis, disease progression, and aggressive phenotype. As proof of concept, JAM-A localizes at endothelial tight junctions, in association with the alphaV $\beta 3$ integrin. Besides being expressed by MM-cells, JAM-A orchestrates MM angiogenesis: upon stimulation with fibroblast growth factor-2 (FGF-2), the JAM-A-alphaV $\beta 3$ complex can dissociate and localizes diffusely along the cell membrane, where it can drive signaling processes, leading to the activation of extracellular signal-regulated MAPK, which leads to angiogenesis and cytoskeleton rearrangement. Trans- homo/heterophilic JAM-A interactions: angiogenesis appears prevalent in MM, as indicated by the results presented in Figure 1 and in $[31,35,101]$. JAM-A binds heterotypically with lymphocyte function-associated antigen-1 (LFA-1), thus promoting potential interactions of MM-cells and endothelial cells with immune cells. These intricate interactions between ligands and receptors within the MM milieu appear to enhance a pro-survival and immunosuppressive environment, where angiogenesis, immune response, and intrinsic tumor cell resistance depend on each other. ADAMTS: A disintegrin and metalloproteinase with thrombospondin motifs 1; AURKA: Aurora kinase A; CD9: CD9 molecule; ENO1: Enolase 1; FGF-2: fibroblast growth factor-2; LFA-1: lymphocyte function-associated antigen 1; MAPK: mitogen-activated protein kinase; PLG: plasminogen; TJP1: tight junction protein-1; $\alpha \mathrm{V} \beta 3$ : integrin alpha V beta 3; VEGFA: vascular endothelial growth factor A. See the results and [35] for additional details. 
A

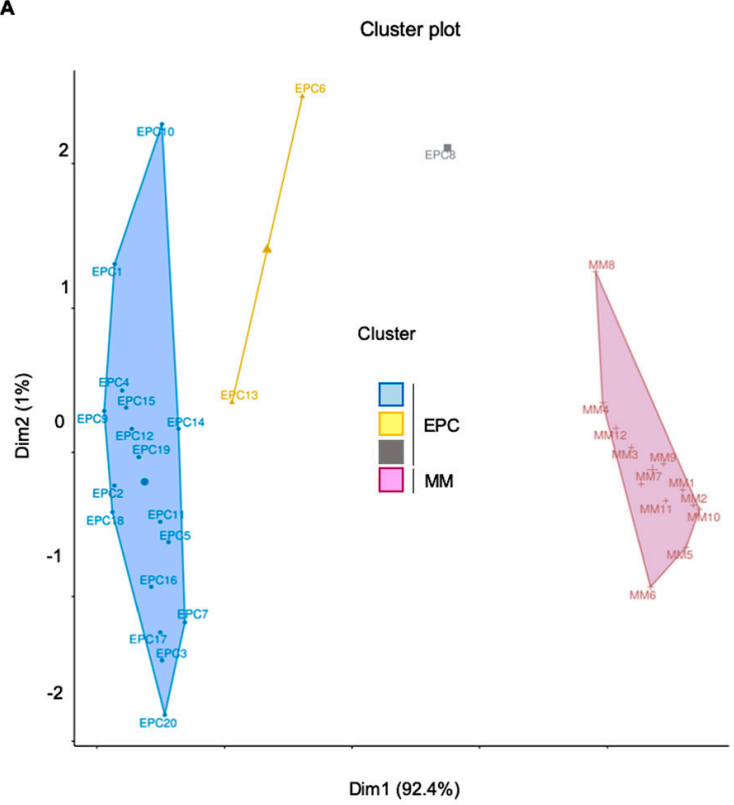

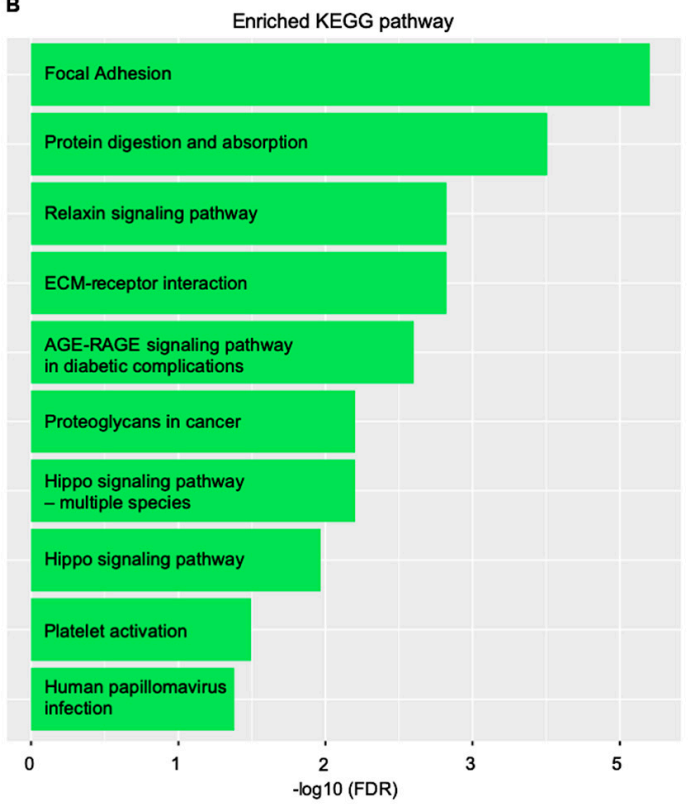

Figure 3. In silico validation confirmed the pivotal role of focal adhesion in sustaining the MM clone. Endothelial cells and MM gene expression supported the bioinformatic findings. (A) K-mean clustering results represented as distribution of samples in clusters. (B) Gene network functional enrichment: histogram representation of significantly enriched KEGG pathways. Overall, focal adhesion and extracellular matrix (ECM)-receptor interaction confirmed the in vitro and ex vivo evidences. Dim: dimension. KEGG: Kyoto Encyclopedia of Genes and Genomes; AGE: advanced glycation end products; EPC: endothelial progenitor cells; FDR: false discovery rate; MM: multiple myeloma plasma cells; RAGE: receptor for advanced glycation endproducts.

Table 1. Endothelial cells function as a gatekeeper for immunological patrolling in solid and hematological malignancies: synthetic overview of the molecular actors. PD-L1, programmed death-ligand 1; IFN $\gamma$, interferon gamma; FGF-2, fibroblast growth factor-2; ICAM, intercellular adhesion molecule; VCAM, vascular cell-adhesion molecule; JAM, junctional adhesion molecule; NEU1, epidermal growth factor like domain 7; VEGF, vascular endothelial growth factor; HLA-E, human leukocyte antigen E; ENO-1, Enolase 1; CCL/CXCL, chemokine ligand; TNF, tumour necrosis factor; NO, nitric oxide; TIM3, T-cell immunoglobulin and mucin domain 3; IDO1, indoleamine 2,3-dioxygenase 1; LFA1, lymphocyte function-associated antigen 1; VLA4, very late antigen 4; VE-cadherin, vascular endothelial cadherin; PECAM1, platelet/endothelial-cell adhesion molecule 1; ESAM, endothelial cell-selective adhesion molecule.

\begin{tabular}{|c|c|c|c|c|}
\hline $\begin{array}{l}\text { Proangiogenic } \\
\text { Molecules* }\end{array}$ & Soluble Factors * & $\begin{array}{l}\text { Immune } \\
\text { Checkpoints }\end{array}$ & $\begin{array}{c}\text { Major } \\
\text { Histocompatibility } \\
\text { Complex (MHC) }\end{array}$ & $\begin{array}{l}\text { Adhesion } \\
\text { Molecules * }\end{array}$ \\
\hline $\begin{array}{c}\text { FGF2 } \\
\text { Modulate selective } \\
\text { up- and } \\
\text { down-regulation } \\
\text { [56,103,104] of } \\
\text { adhesion molecules } \\
\text { (ICAM [30,105], } \\
\text { VCAM [106], JAMs } \\
[35,107,108])\end{array}$ & $\begin{array}{c}\text { Chemokines } \\
\text { (CCL2/18, } \\
\text { CXCL10/11, CXCL4) } \\
\text { Deregulated } \\
\text { chemokines, halting } \\
\text { immune effector } \\
\text { surveillance and } \\
\text { attracting immune } \\
\text { tolerogenic cells } \\
{[27,43,105,109,110]}\end{array}$ & $\begin{array}{c}\text { PD-L1/2 } \\
\text { Cancer endothelium, } \\
\text { also express immune } \\
\text { checkpoints: a cross } \\
\text { talk between } \\
\text { aberrant vasculature, } \\
\text { immune, and cancer } \\
\text { cells creates an } \\
\text { immune permissive } \\
\text { tumor milieu } \\
{[58,101,111-114]}\end{array}$ & $\begin{array}{l}\text { MHC I } \\
\text { Often overexpressed } \\
\text { within the tumor } \\
\text { niche, where the } \\
\text { cancer associated } \\
\text { endothelium is } \\
\text { characterized by a } \\
\text { lack of } \\
\text { co-stimulatory } \\
\text { molecules (B7.1-and } \\
\text { B7.2) [58,115-117] }\end{array}$ & $\begin{array}{c}\text { Selectin-mediated } \\
\text { leukocyte rolling } \\
\text { E-selectin/P-selectin } \\
\text { Orchestrate } \\
\text { leukocyte } \\
\text { recruitment. } \\
{[79,118,119]}\end{array}$ \\
\hline
\end{tabular}


Table 1. Cont.

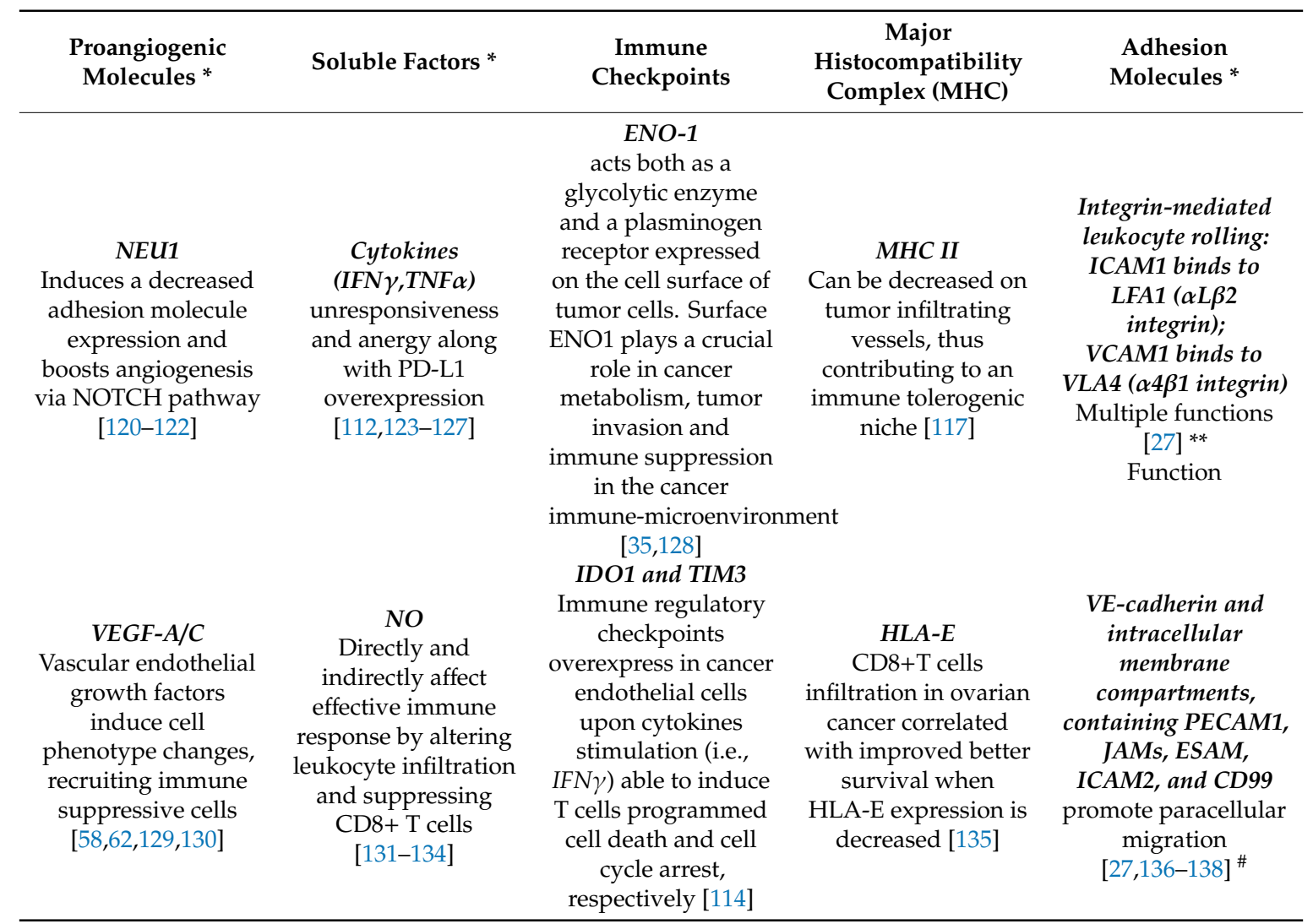

${ }^{*}$ Molecules with demonstrated immunological function influencing microenvironment patrolling are summarized.

** Endothelial cells express selectins and integrins, the most important leukocyte adhesion cascade tumour-associated endothelial cells, express lower levels of cell adhesion molecules, promoting endothelial anergy and reducing the ability of effector T cells to infiltrate tumours. \# Abherrant expression of cancer associated vessels surface proteins contribute to the hypoxia and acidosis, which, in turn, enhance adhesion molecules' expression, recruiting immune-suppressive cells and conversely excluding effector $\mathrm{T}$ cells, by downregulating key integrin and selectins. Adhesion molecules are pivotal in gatekeeping function of endothelial-mediated transmigration.

\section{Measuring T Cell Exit from Tumors: How Do Lymphatic Vessels Shape the Intratumoral Repertoire}

The lymphatic vasculature is a hierarchical network of vessels found within nearly all peripheral tissues. The main function of lymphatic vessels is to unidirectionally transport interstitial fluids proteins and leukocytes from tissue periphery to the draining lymph nodes structure [139]. The organization of lymphatic vessels is uniquely designed to carry out transport functions in tissues and allow leukocyte egress in order to target solid and hematological malignancies [58,140]. The lymphatic system has been explored by several methods, such as in vivo approaches aiming to quantify leukocyte egress upon the uptake of a labeled tracer and microparticle injection [141]. Specifically, pre-labeled cells are injected into the skin, as the most convenient site, and then labeled cells are detected in the draining lymph node, while quantifying the number of migrating lymphocytes as a readout for the amount of egress occurring [141]. Alternatively, interstitial adoptive transfer and intravital microscopy served as lymphatic vasculature investigating tools [142]. In more detail, intravital microscopy allows to actually visualize and track the movements of pre-labeled leukocytes within tissues as well perceive them entering into pre-labeled lymphatics [142]. Moreover, photoconvertible mice using cell type-specific expression of photoconvertible fluorescent protein Kik Green-Red offered a novel strategy to T cell egress quantification in vivo [143,144]. Remarkably, tumor egressed immune cells are transcriptionally distinct from intratumoral T cells [145] and the CD8 T cells seem not to express markers of exhaustion [146]. Of note, a physical barrier to egress enhances adoptive T cell therapy efficacy in preclinical models [130]. On top on this, T cell egress from tumors can represent a potential 
mechanism of immune escape. Nonetheless, the limitations to all these methods are represented by biases in selecting cell types prone to be evaluated for the egress, while the application of a tracer only allows to track cells that can uptake that tracer, namely phagocytic cells. Conversely, by adoptive transfer models, the major caveat is the labeling, limiting the assay to two or three cell types at a time [147]. Even using intravital microscopy, a limited number of labeled leukocytes can be tracked at a single time, and it can also be time-consuming and low throughput for tracking immune cell egress in vivo [147]. Thus, by elucidating the mechanisms that govern egress, it is not only possible to gain a significantly better understanding of how the immune landscape of a tumor is formed, but also to manipulate egress mechanisms in a therapeutically beneficial way [148]. Nonetheless, the translational value of the available finding is still debated and standard histological analysis or flow cytometry profiling of intratumoral leukocyte pools does not really provide any information regarding leukocyte trafficking dynamics [149].

To overcome these caveats, promising new avenues have recently been optimized to study the fate of tumor infiltrating immune cell populations, cancer metastasis, migration patterns of alloreactive $\mathrm{T}$ cells, or the dynamics and plasticity of immune cell subsets in different scenarios such as infection, inflammation, and immunotolerance using the in vivo photoconvertible fluorescence protein "kaede" transgenic mice [143]. The unique property of kaede protein is that it is influenced by violet light pulse exposition. This state-of-the-art method uncovered lymph nodes to be heavily infiltrated with myeloid cells, predominantly inflammatory monocytes and macrophages [150]. However, some lymphocytes in these tumors are also present and the egressing population seems mostly represented by CD4 and CD8 T cells [150]. Collectively, the available shreds of evidence point toward a vicious cycle between the lymph nodal endothelium and the patrolling immune cells, implying that egressed and retained $\mathrm{T}$ cells differ substantially. An acquisition of markers associated with $\mathrm{T}$ cell exhaustion in cells that are retained within the tumor, indicated by high expression of PD1 Tim3 and CD 39, characterizes lymphocytes that are also unable to produce effector cytokines such as interferon gamma and TNF alpha. Contrariwise, $\mathrm{T}$ cells that have passed through the tumor and exited to the draining lymph nodes are not expressing markers of exhaustion and retain their ability to produce effector cytokines [151]. It might be advantageous to keep these tumor-specific $\mathrm{T}$ cells within the tumor for a much longer period of time, potentially improving their function. Despite that direct translation of subclasses based on the vascular phenotype into clinical decision-making is yet to be achieved, these findings may also point towards a potential Achilles' heel of multiple cancer that might be exploited therapeutically.

\section{Boosting Cancer Immunotherapy Using Anti-Angiogenics: Therapeutic Windows and Challenges Offered by the Visualization and Reprogramming of the Tumor Milieu}

Across the timeline of the development of various imaging techniques, both clinical and preclinical models greatly contributed to the imaging of tumor vasculature and microenvironment [152-156]. The translational value of imaging tumor blood vessels allowed to identify the abnormal microvasculature, visualizing the shape and diameter, the vessel wall, the abnormal branching, and even the blood flow, characterizing the level of heterogeneity in vivo [157]. Based on these pieces of evidence, cancer vasculature appears to be functionally abnormal [158], corroborating previous findings regarding abnormal blood flow as a consequence of aberrant vessel formation [158,159]. While comparing with normal vessels in the cancer tissue, there is a lack of correlation between the size of the vessels' diameter and red blood cells velocity [158,159]. Remarkably, the next generation of experimental immunodiagnostics in cancer model also provided imaging understandings regarding immune cell trafficking in tumour vessels, namely monocytes, interacting with the vessel wall [155] and leading to patrolling immune cells' recruitment. From the above mentioned standpoint, the traditional anti-angiogenesis can deeply affect anti-tumour immunity, as full doses of drugs shrink the tumor, leading to cancer hypoxia and priming immune suppressive cells' infiltration [160]. A wise use of therapeutic strategies halting the cancer angiogenesis must thus take into account the abnormal metabolic microenvironment characterizing a heterogeneous 
oxygenation [161,162]. Assessing oxygenation in the different layers of tumour pinpoint that there is a progressive increase of nutrient and oxygen levels across the inner depth [162], thus fueling genomic instability [163], the cancer progression (PD) [16], the switch to anaerobic metabolism [164], as well as the epithelial-mesenchymal transition, metastases [165], and the induction of cancer "stem cell" phenotype [166]. Hypoxia is a hallmark of cancer, inducing many abnormalities with prognostic consequences linked to defects in apoptosis and autophagy $[167,168]$ and the resistance to radio-chemotherapy [169-171] and immunotherapy $[13,172,173]$ likewise hamper the cancer aggressive phenotype acquisition, while shaping a pro-angiogenic, inflamed, and immunosuppressive neoplastic ecosystem $[154,174,175]$. Consequently, it is necessary either to target many different actors on the scene within the neoplastic niche or attempt to homogenize the cancer heterogeneity [161].

\section{Hypoxia as a Key Factor for Angiogenesis and Immune Equilibrium}

Sufficient oxygen pressure is required for our organs to function properly. Conversely, insufficient oxygen supply is a prominent feature in various pathological processes, including tumor development and metastasis [176,177]. Hypoxic malignant cells are more prone to increase their genetic instability [178], while decreasing the immune response. Moreover, insufficient oxygen supply influences ECM remodeling and stiffness [179], further halting the susceptibility to chemotherapy and radiation therapy [180]. Notably, the enhanced angiogenesis is deemed to counteract the neoplastic metabolic and energetic need, but also shapes the tumor microenvironment and boosts the malignant cells faculty to gain immunosuppression, fueling the cancer progression [181].

The association of cell signaling driving cellular adaptation to hypoxia prompted the investigation on targets that might halt the proliferation of hypoxic tumors if halted. The three pivotal oxygen-dependent molecular mechanism during metabolic adaptation rely on hypoxia inducible factors (HIF members), unfolded protein response (UPR) [182], and mammalian target of rapamycin (mTOR) [8]. Specific targeting of hypoxia in cancer therapy has been extensively investigated and trials exploiting hypoxia-dependent druggable signaling are ongoing [181,183].

Nonetheless, normalizing the tumor vasculature with the judicious use of antiangiogenics can revert this process, directing intervening in oxygen delivery [184-186].

As proangiogenic factors typically predominate, tumour perfusion and oxygenation are usually impaired; the re-establishment of physiologic equilibrium aims to vasogenic edema and interstitial pressure reduction, while enhancing the drug delivery and indirectly reducing neoplastic cells shedding and invasiveness $[160,187]$. A paradigmatic example of in vivo modelling of judicious use of anti-angiogenic treatment has been pioneered by Winkler et al. using anti-VEGFR2 targeting in glioblastoma multiforme (GBM), able to increase pericyte coverage in mature vessels [188], and further corroborated in other tumour types $[153,189]$. Because of this improvement in the vessels' structure, functional consequences such as radiation and anti-angiogenic synergism occur during the vessel "normalization window" [188]. The pericyte recruitment parallels angiopoietin-1 (Ang1) and angiopoietin-2 (Ang2) crosstalk. Ang1 promotes vessel maturation and survival through Tie-2 receptor phosphorylation and via the PI3K-AKT-mediated signaling pathway. The development that follows after the formation of immature vessels is mainly due to Ang1 and ephrin B2. Conversely, Ang2 is a context-dependent molecule that counterbalances Ang1 [190,191]. Thus, the Ang1/Ang2 ratio might correlate with vascular normalization [188]. Notably, Ang2 overexpression decreases the prognostic advantage gained by anti-VEGFR strategies [192], uncovering Ang2 to be a rate-determining step for anti-VEGFR treatment. In fact, the dual anti-Ang2/VEGFRs therapy has been shown to enhance the length of the window of vessel normalization in vivo, thus achieving survival improvement and tumour burden reduction upon dual VEGFR2-Ang2 inhibition [193]. These treatment effects of simultaneous VEGFR and Ang2 halting were observed in preclinical models, not in patients and, therefore, must be translated with carefulness. Nonetheless, reprogramming of tumour milieu for immunotherapeutical purposes seems to be conceivable because of the plethora of pathophysiological effects played by VEGF on the immune innate and adaptive compartment [160,194], by enhancing the recruitment 
and proliferation of cancer tolerogenic Tregs cells [195] and tumour associate macrophages (TAM). Both actors nurse the milieu, making it tolerogenic, and feed into auto-paracrine myeloid-derived suppressor cells (MDSCs) [196] via VEGF and break cytotoxic T lymphocytes' (CTLs) effector functions [58,197]. Collectively, the abnormal cancer vasculature contributes to immunosuppression in the niche $[194,198-200]$ and enhances the shedding of systemic factors hijacking the anti-cancer response [22,198,201].

Current advances in tumour immunotherapy consent to proficiently unleash immune effector cells [202]. What ensues is an immune-supportive skewing, also originating from the vascular normalization $[23,203]$. Typically, the highest anti-angiogenic doses have been employed at the maximum tolerated doses until PD. Nonetheless, the dosage is key because increasing the amount and a sustained extent of anti-angiogenic therapy are themselves associated with cancer hypoxia and, eventually, PD $[23,198,204]$. The insights regarding the window of normalized perfusion from vascular normalization depend on the dose and potency of the antiangiogenic therapy. Precisely, the degree of neo-vessels normalization in localized and disseminated cancers is liable determined by the dose of anti-angiogenic compounds and the amount of the angiogenic stimulus in the given neoplasia [204]. Disproportionate perfusion reduction can boost oxidative stress and dissemination potential, while halting the immune infiltrate $[205,206]$. Therefore, as the stage of normalized cancer oxygen delivery after tailored anti-angiogenic treatment is transitory, the choice of the proper timing matching the vascular normalization "window", the tailored dose of anti-angiogenic treatment, as well as the most effective immune-modulatory agent appear critical. An elevated concentration and therapy extent of anti-VEGF therapy are associated with decreased cancer oxygen supply and elevated hypoxia [23]. Notably, pre-clinical models uncovered a lower concentration of anti-angiogenic agents to be correlated with sustained vascular normalization [22,198], as low as one-quarter of the conventional dose. Clinical studies corroborated these findings, demonstrating that a decreased dose of anti-VEGF ( $<3.6 \mathrm{mg} / \mathrm{kg}$, weekly) combined with cytoreduction resulted in improved survival over a high dose (5 mg/kg, week) in subjects suffering from glioblastoma [207,208]. Many attempts have been proposed to unbridle an effective immune response while breaking the vicious cycle between abnormal angiogenesis and immune patrolling actors in aggressive and refractory malignancies [209-211] Collectively, the combination of angiogenesis and immunity targeting has been studied a lot in pre-clinical as well as clinical settings, some of them showing promising results $[160,212,213]$. Overall, the knowledge on the abnormal vasculature and microenvironment provides the backbone for normalization of tumour vasculature strategy, with the judicious use of antiangiogenics and niche reprogramming with the goal of immunotherapy improvement [161].

\section{Conclusions}

Critical mechanisms fostering blood and lymphatic vessels' formation and facilitating immunosuppression throughout tumor growth and progression have been uncovered. Cancer cells grow and progress through a persistent crosstalk with the neighboring milieu. Next generation techniques sketch at a high resolution such that the new vessels' formation and immune paresis regularly occur to fuel this vicious cycle. Consequently, state-of-the-art therapeutic strategies merging anti-angiogenic and immune-directed treatments appear to hold promise to shape the neoplastic ecosystem and boost the therapeutic efficacy.

Author Contributions: Conceptualization, D.R., A.G.S., and A.V.; methodology, A.G.S. and S.D.S.; software, S.D.S. and A.G.S.; validation, D.R. and A.V.; formal analysis, A.G.S. and S.D.S.; investigation, A.G.S. and D.R.; resources, A.G.S., D.R., and A.V.; data curation, A.G.S. and S.D.S.; writing-original draft preparation, A.G.S., D.R., and A.V.; writing-review and editing, D.R., and A.V; visualization, A.G.S. and S.D.S.; supervision, D.R. and A.V.; project administration, D.R. and A.G.S.; funding acquisition, D.R., A.G.S., and A.V. All authors have read and agreed to the published version of the manuscript. 
Funding: This research was funded by GLOBALDOC Project-CUP H96J17000160002 approved with A.D. n. 9 on 18 January 2017, from Puglia Region, financed under the Action Plan for Cohesion approved with Commission decision C (2016) 1417 of 3 March 2016 to A.G.S., as well as the Apulian Regional project: medicina di precisione to A.G.S.

Acknowledgments: We thank Antonella Argentiero and Matteo Claudio Da Vià for technical support and valuable discussions. We also thank Mary Victoria Pragnell and Maria Gemma Pizzolla for linguistic editing.

Conflicts of Interest: The authors declare no conflict of interest.

\section{Abbreviations}

\begin{tabular}{|c|c|}
\hline CCL & Chemokine ligand \\
\hline CXCL & Chemokine ligand \\
\hline ENO1 & Enolase1 \\
\hline ESAM & Endothelial cell-selective adhesion molecule \\
\hline FGF2 & Fibroblast growth factor 2 \\
\hline ICAM & Intercellular adhesion molecule \\
\hline IDO1 & Indoleamine 2,3-Dioxygenase 1 \\
\hline HLA-E & Human leukocyte antigen E \\
\hline $\mathrm{IFN} \gamma$ & Interferon gamma \\
\hline JAMs & Junctional adhesion molecules \\
\hline LFA1 & Lymphocyte function-associated antigen 1 (also known as $\alpha \mathrm{L} \beta 2$-integrin) \\
\hline $\mathrm{MHC}$ & Major histocompatibility complex \\
\hline NEU1 & Epidermal growth factor like domain 7 (Egfl7) \\
\hline NO & Nitric oxide \\
\hline PD-L1/2 & Programmed death-ligand 1/2 \\
\hline PECAM1 & Platelet/endothelial-cell adhesion molecule 1 \\
\hline TIM3 & T-cell immunoglobulin and mucin domain 3 \\
\hline $\mathrm{TNF} \alpha$ & Tumour necrosis factor alpha \\
\hline VCAM & Vascular cell-adhesion molecule \\
\hline VE-cadherin & Vascular endothelial cadherin \\
\hline VEGF & Vascular endothelial growth factor \\
\hline VLA4 & Very late antigen 4 (also known as $\alpha 4 \beta 1$-integrin) \\
\hline
\end{tabular}

\section{References}

1. Kerbel, R.S. Tumor angiogenesis. N. Engl. J. Med. 2008, 358, 2039-2049. [CrossRef] [PubMed]

2. Baeriswyl, V.; Christofori, G. The angiogenic switch in carcinogenesis. Semin. Cancer Biol. 2009, 19, 329-337. [CrossRef] [PubMed]

3. Ribatti, D.; Nico, B.; Crivellato, E.; Roccaro, A.M.; Vacca, A. The history of the angiogenic switch concept. Leukemia 2007, 21, 44-52. [CrossRef] [PubMed]

4. Ribatti, D.; Vacca, A.; Presta, M. The discovery of angiogenic factors. Gen. Pharmacol. Vasc. Syst. 2000, 35, 227-231. [CrossRef]

5. Vermeulen, P.B.; Gasparini, G.; Fox, S.B.; Toi, M.; Martin, L.; Mcculloch, P.; Pezzella, F.; Viale, G.; Weidner, N.; Harris, A.L.; et al. Quantification of angiogenesis in solid human tumours: An international consensus on the methodology and criteria of evaluation. Eur. J. Cancer 1996, 32, 2474-2484. [CrossRef]

6. Hasan, J.; Byers, R.; Jayson, G.C. Intra-tumoural microvessel density in human solid tumours. Br. J. Cancer 2002, 86, 1566-1577. [CrossRef]

7. Leone, P.; Buonavoglia, A.; Fasano, R.; Solimando, A.G.; De Re, V.; Cicco, S.; Vacca, A.; Racanelli, V. Insights into the Regulation of Tumor Angiogenesis by Micro-RNAs. J. Clin. Med. 2019, 8, 2030. [CrossRef]

8. Lamanuzzi, A.; Saltarella, I.; Desantis, V.; Frassanito, M.A.; Leone, P.; Racanelli, V.; Nico, B.; Ribatti, D.; Ditonno, P.; Prete, M.; et al. Inhibition of mTOR complex 2 restrains tumor angiogenesis in multiple myeloma. Oncotarget 2018, 9, 20563-20577. [CrossRef]

9. Li, W.W.; Hutnik, M.; Gehr, G. Antiangiogenesis in haematological malignancies. Br. J. Haematol. 2008, 143, 622-631. [CrossRef] 
10. Hendrix, M.J.C.; Seftor, E.A.; Seftor, R.E.B.; Chao, J.-T.; Chien, D.-S.; Chu, Y.-W. Tumor cell vascular mimicry: Novel targeting opportunity in melanoma. Pharmacol. Ther. 2016, 159, 83-92. [CrossRef]

11. Folkman, J. Angiogenesis. In Biology of Endothelial Cells; Jaffe, E.A., Ed.; Developments in Cardiovascular Medicine; Springer: Boston, MA, USA, 1984; Volume 27, pp. 412-428. ISBN 978-1-4612-9786-4.

12. Moserle, L.; Jimenez-Valerio, G.; Casanovas, O. Antiangiogenic Therapies: Going beyond Their Limits. Cancer Discov. 2014, 4, 31-41. [CrossRef] [PubMed]

13. Argentiero, A.; Solimando, A.G.; Krebs, M.; Leone, P.; Susca, N.; Brunetti, O.; Racanelli, V.; Vacca, A.; Silvestris, N. Anti-angiogenesis and Immunotherapy: Novel Paradigms to Envision Tailored Approaches in Renal Cell-Carcinoma. J. Clin. Med. 2020, 9, 1594. [CrossRef] [PubMed]

14. Sakariassen, P.O.; Prestegarden, L.; Wang, J.; Skaftnesmo, K.-O.; Mahesparan, R.; Molthoff, C.; Sminia, P.; Sundlisaeter, E.; Misra, A.; Tysnes, B.B.; et al. Angiogenesis-independent tumor growth mediated by stem-like cancer cells. Proc. Natl. Acad. Sci. USA 2006, 103, 16466-16471. [CrossRef] [PubMed]

15. Junttila, M.R.; de Sauvage, F.J. Influence of tumour micro-environment heterogeneity on therapeutic response. Nature 2013, 501, 346-354. [CrossRef] [PubMed]

16. Muz, B.; de la Puente, P.; Azab, F.; Azab, A.K. The role of hypoxia in cancer progression, angiogenesis, metastasis, and resistance to therapy. Hypoxia Auckl. N. Z. 2015, 3, 83-92. [CrossRef] [PubMed]

17. Sozzani, S.; Rusnati, M.; Riboldi, E.; Mitola, S.; Presta, M. Dendritic cell-endothelial cell cross-talk in angiogenesis. Trends Immunol. 2007, 28, 385-392. [CrossRef] [PubMed]

18. Zuazo-Gaztelu, I.; Casanovas, O. Unraveling the Role of Angiogenesis in Cancer Ecosystems. Front. Oncol. 2018, 8, 248. [CrossRef]

19. Hanahan, D.; Weinberg, R.A. Hallmarks of Cancer: The Next Generation. Cell 2011, 144, 646-674. [CrossRef]

20. Abdalla, A.M.E.; Xiao, L.; Ullah, M.W.; Yu, M.; Ouyang, C.; Yang, G. Current Challenges of Cancer Anti-angiogenic Therapy and the Promise of Nanotherapeutics. Theranostics 2018, 8, 533-548. [CrossRef]

21. Joyce, J.A.; Fearon, D.T. T cell exclusion, immune privilege, and the tumor microenvironment. Science 2015, 348, 74-80. [CrossRef]

22. Huang, Y.; Goel, S.; Duda, D.G.; Fukumura, D.; Jain, R.K. Vascular normalization as an emerging strategy to enhance cancer immunotherapy. Cancer Res. 2013, 73, 2943-2948. [CrossRef] [PubMed]

23. Huang, Y.; Yuan, J.; Righi, E.; Kamoun, W.S.; Ancukiewicz, M.; Nezivar, J.; Santosuosso, M.; Martin, J.D.; Martin, M.R.; Vianello, F.; et al. Vascular normalizing doses of antiangiogenic treatment reprogram the immunosuppressive tumor microenvironment and enhance immunotherapy. Proc. Natl. Acad. Sci. USA 2012, 109, 17561-17566. [CrossRef] [PubMed]

24. Morikawa, S.; Baluk, P.; Kaidoh, T.; Haskell, A.; Jain, R.K.; McDonald, D.M. Abnormalities in pericytes on blood vessels and endothelial sprouts in tumors. Am. J. Pathol. 2002, 160, 985-1000. [CrossRef]

25. Fisher, D.T.; Muhitch, J.B.; Kim, M.; Doyen, K.C.; Bogner, P.N.; Evans, S.S.; Skitzki, J.J. Intraoperative intravital microscopy permits the study of human tumour vessels. Nat. Commun. 2016, 7, 10684. [CrossRef] [PubMed]

26. Galon, J.; Bruni, D. Approaches to treat immune hot, altered and cold tumours with combination immunotherapies. Nat. Rev. Drug Discov. 2019, 18, 197-218. [CrossRef]

27. Ley, K.; Laudanna, C.; Cybulsky, M.I.; Nourshargh, S. Getting to the site of inflammation: The leukocyte adhesion cascade updated. Nat. Rev. Immunol. 2007, 7, 678-689. [CrossRef]

28. Lu, P.; Takai, K.; Weaver, V.M.; Werb, Z. Extracellular matrix degradation and remodeling in development and disease. Cold Spring Harb. Perspect. Biol. 2011, 3. [CrossRef]

29. Da Vià, M.C.; Solimando, A.G.; Garitano-Trojaola, A.; Barrio, S.; Munawar, U.; Strifler, S.; Haertle, L.; Rhodes, N.; Teufel, E.; Vogt, C.; et al. CIC Mutation as a Molecular Mechanism of Acquired Resistance to Combined BRAF-MEK Inhibition in Extramedullary Multiple Myeloma with Central Nervous System Involvement. Oncologist 2019. [CrossRef]

30. Harjunpää, H.; Llort Asens, M.; Guenther, C.; Fagerholm, S.C. Cell Adhesion Molecules and Their Roles and Regulation in the Immune and Tumor Microenvironment. Front. Immunol. 2019, 10, 1078. [CrossRef]

31. Solimando, A.G.; Brandl, A.; Mattenheimer, K.; Graf, C.; Ritz, M.; Ruckdeschel, A.; Stühmer, T.; Mokhtari, Z.; Rudelius, M.; Dotterweich, J.; et al. JAM-A as a prognostic factor and new therapeutic target in multiple myeloma. Leukemia 2018, 32, 736-743. [CrossRef]

32. Rudelius, M.; Rosenfeldt, M.T.; Leich, E.; Rauert-Wunderlich, H.; Solimando, A.G.; Beilhack, A.; Ott, G.; Rosenwald, A. Inhibition of focal adhesion kinase overcomes resistance of mantle cell lymphoma to ibrutinib in the bone marrow microenvironment. Haematologica 2018, 103, 116-125. [CrossRef] [PubMed] 
33. Anderson, A.R.A. A hybrid mathematical model of solid tumour invasion: The importance of cell adhesion. Math. Med. Biol. J. IMA 2005, 22, 163-186. [CrossRef] [PubMed]

34. Argentiero, A.; Calabrese, A.; Solimando, A.G.; Notaristefano, A.; Panarelli, M.M.G.; Brunetti, O. Bone metastasis as primary presentation of pancreatic ductal adenocarcinoma: A case report and literature review. Clin. Case Rep. 2019, 7, 1972-1976. [CrossRef] [PubMed]

35. Solimando, A.G.; Da Vià, M.C.; Leone, P.; Borrelli, P.; Croci, G.A.; Tabares, P.; Brandl, A.; Di Lernia, G.; Bianchi, F.P.; Tafuri, S.; et al. Halting the vicious cycle within the multiple myeloma ecosystem: Blocking JAM-A on bone marrow endothelial cells restores the angiogenic homeostasis and suppresses tumor progression. Haematologica 2020. [CrossRef]

36. Moghadam, A.R.; Patrad, E.; Tafsiri, E.; Peng, W.; Fangman, B.; Pluard, T.J.; Accurso, A.; Salacz, M.; Shah, K.; Ricke, B.; et al. Ral signaling pathway in health and cancer. Cancer Med. 2017, 6, 2998-3013. [CrossRef]

37. Solimando, A.G.; Ribatti, D.; Vacca, A.; Einsele, H. Targeting B-cell non Hodgkin lymphoma: New and old tricks. Leuk. Res. 2016, 42, 93-104. [CrossRef]

38. Farahani, E.; Patra, H.K.; Jangamreddy, J.R.; Rashedi, I.; Kawalec, M.; Rao Pariti, R.K.; Batakis, P.; Wiechec, E. Cell adhesion molecules and their relation to (cancer) cell stemness. Carcinogenesis 2014, 35,747-759. [CrossRef]

39. Seibold, M.; Stühmer, T.; Kremer, N.; Mottok, A.; Scholz, C.-J.; Schlosser, A.; Leich, E.; Holzgrabe, U.; Brünnert, D.; Barrio, S.; et al. RAL GTPases mediate multiple myeloma cell survival and are activated independently of oncogenic RAS. Haematologica 2019. [CrossRef]

40. Wu, N.Z.; Klitzman, B.; Dodge, R.; Dewhirst, M.W. Diminished leukocyte-endothelium interaction in tumor microvessels. Cancer Res. 1992, 52, 4265-4268.

41. Ganss, R.; Hanahan, D. Tumor microenvironment can restrict the effectiveness of activated antitumor lymphocytes. Cancer Res. 1998, 58, 4673-4681.

42. Hamzah, J.; Jugold, M.; Kiessling, F.; Rigby, P.; Manzur, M.; Marti, H.H.; Rabie, T.; Kaden, S.; Gröne, H.-J.; Hämmerling, G.J.; et al. Vascular normalization in Rgs5-deficient tumours promotes immune destruction. Nature 2008, 453, 410-414. [CrossRef] [PubMed]

43. Lambrechts, D.; Wauters, E.; Boeckx, B.; Aibar, S.; Nittner, D.; Burton, O.; Bassez, A.; Decaluwé, H.; Pircher, A.; Van den Eynde, K.; et al. Phenotype molding of stromal cells in the lung tumor microenvironment. Nat. Med. 2018, 24, 1277-1289. [CrossRef] [PubMed]

44. Zavidij, O.; Haradhvala, N.J.; Mouhieddine, T.H.; Sklavenitis-Pistofidis, R.; Cai, S.; Reidy, M.; Rahmat, M.; Flaifel, A.; Ferland, B.; Su, N.K.; et al. Single-cell RNA sequencing reveals compromised immune microenvironment in precursor stages of multiple myeloma. Nat. Cancer 2020, 1, 493-506. [CrossRef]

45. Couzin-Frankel, J. Cancer Immunotherapy. Science 2013, 342, 1432-1433. [CrossRef]

46. Robert, C. A decade of immune-checkpoint inhibitors in cancer therapy. Nat. Commun. 2020, 11, 3801. [CrossRef]

47. Siu, L.L.; Ivy, S.P.; Dixon, E.L.; Gravell, A.E.; Reeves, S.A.; Rosner, G.L. Challenges and Opportunities in Adapting Clinical Trial Design for Immunotherapies. Clin. Cancer Res. Off. J. Am. Assoc. Cancer Res. 2017, 23, 4950-4958. [CrossRef]

48. Nishino, M.; Ramaiya, N.H.; Hatabu, H.; Hodi, F.S. Monitoring immune-checkpoint blockade: Response evaluation and biomarker development. Nat. Rev. Clin. Oncol. 2017, 14, 655-668. [CrossRef]

49. Solimando, A.G.; Crudele, L.; Leone, P.; Argentiero, A.; Guarascio, M.; Silvestris, N.; Vacca, A.; Racanelli, V. Immune Checkpoint Inhibitor-Related Myositis: From Biology to Bedside. Int. J. Mol. Sci. 2020, 21, 3054. [CrossRef]

50. Martins, F.; Sofiya, L.; Sykiotis, G.P.; Lamine, F.; Maillard, M.; Fraga, M.; Shabafrouz, K.; Ribi, C.; Cairoli, A.; Guex-Crosier, Y.; et al. Adverse effects of immune-checkpoint inhibitors: Epidemiology, management and surveillance. Nat. Rev. Clin. Oncol. 2019, 16, 563-580. [CrossRef]

51. Larkin, J.; Chiarion-Sileni, V.; Gonzalez, R.; Grob, J.-J.; Rutkowski, P.; Lao, C.D.; Cowey, C.L.; Schadendorf, D.; Wagstaff, J.; Dummer, R.; et al. Five-Year Survival with Combined Nivolumab and Ipilimumab in Advanced Melanoma. N. Engl. J. Med. 2019, 381, 1535-1546. [CrossRef]

52. Motzer, R.J.; Tannir, N.M.; McDermott, D.F.; Arén Frontera, O.; Melichar, B.; Choueiri, T.K.; Plimack, E.R.; Barthélémy, P.; Porta, C.; George, S.; et al. Nivolumab plus Ipilimumab versus Sunitinib in Advanced Renal-Cell Carcinoma. N. Engl. J. Med. 2018, 378, 1277-1290. [CrossRef] [PubMed]

53. Martin, J.D.; Cabral, H.; Stylianopoulos, T.; Jain, R.K. Improving cancer immunotherapy using nanomedicines: Progress, opportunities and challenges. Nat. Rev. Clin. Oncol. 2020, 17, 251-266. [CrossRef] [PubMed]

54. Khan, K.A.; Kerbel, R.S. Improving immunotherapy outcomes with anti-angiogenic treatments and vice versa. Nat. Rev. Clin. Oncol. 2018, 15, 310-324. [CrossRef] [PubMed] 
55. Balamurugan, K. HIF-1 at the crossroads of hypoxia, inflammation, and cancer. Int. J. Cancer 2016, 138, 1058-1066. [CrossRef] [PubMed]

56. Huang, Y.; Kim, B.Y.S.; Chan, C.K.; Hahn, S.M.; Weissman, I.L.; Jiang, W. Improving immune-vascular crosstalk for cancer immunotherapy. Nat. Rev. Immunol. 2018, 18, 195-203. [CrossRef]

57. Liu, Y.; Shaw, S.K.; Ma, S.; Yang, L.; Luscinskas, F.W.; Parkos, C.A. Regulation of Leukocyte Transmigration: Cell Surface Interactions and Signaling Events. J. Immunol. 2004, 172, 7-13. [CrossRef] [PubMed]

58. Leone, P.; Di Lernia, G.; Solimando, A.G.; Cicco, S.; Saltarella, I.; Lamanuzzi, A.; Ria, R.; Frassanito, M.A.; Ponzoni, M.; Ditonno, P.; et al. Bone marrow endothelial cells sustain a tumor-specific CD8+ T cell subset with suppressive function in myeloma patients. Oncoimmunology 2019, 8, e1486949. [CrossRef]

59. Chae, Y.K.; Choi, W.M.; Bae, W.H.; Anker, J.; Davis, A.A.; Agte, S.; Iams, W.T.; Cruz, M.; Matsangou, M.; Giles, F.J. Overexpression of adhesion molecules and barrier molecules is associated with differential infiltration of immune cells in non-small cell lung cancer. Sci. Rep. 2018, 8, 1023. [CrossRef]

60. Orecchioni, M.; Ghosheh, Y.; Pramod, A.B.; Ley, K. Macrophage Polarization: Different Gene Signatures in M1(LPS+) vs. Classically and M2(LPS-) vs. Alternatively Activated Macrophages. Front. Immunol. 2019, 10, 1084. [CrossRef]

61. Porcelli, L.; Iacobazzi, R.M.; Di Fonte, R.; Serratì, S.; Intini, A.; Solimando, A.G.; Brunetti, O.; Calabrese, A.; Leonetti, F.; Azzariti, A.; et al. CAFs and TGF- $\beta$ Signaling Activation by Mast Cells Contribute to Resistance to Gemcitabine/Nabpaclitaxel in Pancreatic Cancer. Cancers 2019, 11, 330. [CrossRef]

62. Albini, A.; Bruno, A.; Noonan, D.M.; Mortara, L. Contribution to Tumor Angiogenesis from Innate Immune Cells Within the Tumor Microenvironment: Implications for Immunotherapy. Front. Immunol. 2018, 9, 527. [CrossRef] [PubMed]

63. Quail, D.F.; Joyce, J.A. Microenvironmental regulation of tumor progression and metastasis. Nat. Med. 2013, 19, 1423-1437. [CrossRef] [PubMed]

64. Argentiero, A.; De Summa, S.; Di Fonte, R.; Iacobazzi, R.M.; Porcelli, L.; Da Vià, M.; Brunetti, O.; Azzariti, A.; Silvestris, N.; Solimando, A.G. Gene Expression Comparison between the Lymph Node-Positive and -Negative Reveals a Peculiar Immune Microenvironment Signature and a Theranostic Role for WNT Targeting in Pancreatic Ductal Adenocarcinoma: A Pilot Study. Cancers 2019, 11, 942. [CrossRef] [PubMed]

65. Tian, L.; Goldstein, A.; Wang, H.; Ching Lo, H.; Sun Kim, I.; Welte, T.; Sheng, K.; Dobrolecki, L.E.; Zhang, X.; Putluri, N.; et al. Mutual regulation of tumour vessel normalization and immunostimulatory reprogramming. Nature 2017, 544, 250-254. [CrossRef] [PubMed]

66. Zheng, X.; Fang, Z.; Liu, X.; Deng, S.; Zhou, P.; Wang, X.; Zhang, C.; Yin, R.; Hu, H.; Chen, X.; et al. Increased vessel perfusion predicts the efficacy of immune checkpoint blockade. J. Clin. Investig. 2018, 128, 2104-2115. [CrossRef]

67. Hill, J.M.; Zalos, G.; Halcox, J.P.J.; Schenke, W.H.; Waclawiw, M.A.; Quyyumi, A.A.; Finkel, T. Circulating endothelial progenitor cells, vascular function, and cardiovascular risk. N. Engl. J. Med. 2003, 348, 593-600. [CrossRef]

68. Goon, P.K.Y.; Lip, G.Y.H.; Boos, C.J.; Stonelake, P.S.; Blann, A.D. Circulating endothelial cells, endothelial progenitor cells, and endothelial microparticles in cancer. Neoplasia N. Y. 2006, 8, 79-88. [CrossRef]

69. Gao, D.; Nolan, D.J.; Mellick, A.S.; Bambino, K.; McDonnell, K.; Mittal, V. Endothelial progenitor cells control the angiogenic switch in mouse lung metastasis. Science 2008, 319, 195-198. [CrossRef]

70. Moschetta, M.; Mishima, Y.; Kawano, Y.; Manier, S.; Paiva, B.; Palomera, L.; Aljawai, Y.; Calcinotto, A.; Unitt, C.; Sahin, I.; et al. Targeting vasculogenesis to prevent progression in multiple myeloma. Leukemia 2016, 30, 1103-1115. [CrossRef]

71. Moschetta, M.; Mishima, Y.; Sahin, I.; Manier, S.; Glavey, S.; Vacca, A.; Roccaro, A.M.; Ghobrial, I.M. Role of endothelial progenitor cells in cancer progression. Biochim. Biophys. Acta 2014, 1846, 26-39. [CrossRef]

72. Rajkumar, S.V.; Dimopoulos, M.A.; Palumbo, A.; Blade, J.; Merlini, G.; Mateos, M.-V.; Kumar, S.; Hillengass, J.; Kastritis, E.; Richardson, P.; et al. International Myeloma Working Group updated criteria for the diagnosis of multiple myeloma. Lancet Oncol. 2014, 15, e538-e548. [CrossRef]

73. Vacca, A.; Melaccio, A.; Sportelli, A.; Solimando, A.G.; Dammacco, F.; Ria, R. Subcutaneous immunoglobulins in patients with multiple myeloma and secondary hypogammaglobulinemia: A randomized trial. Clin. Immunol. 2018, 191, 110-115. [CrossRef] [PubMed]

74. Nucci, M.; Anaissie, E. Infections in Patients with Multiple Myeloma in the Era of High-Dose Therapy and Novel Agents. Clin. Infect. Dis. 2009, 49, 1211-1225. [CrossRef] [PubMed] 
75. Ria, R.; Reale, A.; Solimando, A.G.; Mangialardi, G.; Moschetta, M.; Gelao, L.; Iodice, G.; Vacca, A. Induction therapy and stem cell mobilization in patients with newly diagnosed multiple myeloma. Stem Cells Int. 2012, 2012, 607260. [CrossRef] [PubMed]

76. Cicco, S.; Solimando, A.G.; Leone, P.; Battaglia, S.; Ria, R.; Vacca, A.; Racanelli, V. Suspected Pericardial Tuberculosis Revealed as an Amyloid Pericardial Mass. Case Rep. Hematol. 2018, 2018, 8606430. [CrossRef] [PubMed]

77. Solimando, A.G.; Sportelli, A.; Troiano, T.; Demarinis, L.; Di Serio, F.; Ostuni, A.; Dammacco, F.; Vacca, A.; Ria, R. A multiple myeloma that progressed as type I cryoglobulinemia with skin ulcers and foot necrosis: A case report. Medicine 2018, 97, e12355. [CrossRef]

78. Cicco, S.; Solimando, A.G.; Buono, R.; Susca, N.; Inglese, G.; Melaccio, A.; Prete, M.; Ria, R.; Racanelli, V.; Vacca, A. Right Heart Changes Impact on Clinical Phenotype of Amyloid Cardiac Involvement: A Single Centre Study. Life 2020, 10, 247. [CrossRef]

79. Di Marzo, L.; Desantis, V.; Solimando, A.G.; Ruggieri, S.; Annese, T.; Nico, B.; Fumarulo, R.; Vacca, A.; Frassanito, M.A. Microenvironment drug resistance in multiple myeloma: Emerging new players. Oncotarget 2016, 7, 60698-60711. [CrossRef]

80. Manier, S.; Sacco, A.; Leleu, X.; Ghobrial, I.M.; Roccaro, A.M. Bone marrow microenvironment in multiple myeloma progression. J. Biomed. Biotechnol. 2012, 2012, 157496. [CrossRef]

81. Solimando, A.G.; Vacca, A.; Ribatti, D. A Comprehensive Biological and Clinical Perspective Can Drive a Patient-Tailored Approach to Multiple Myeloma: Bridging the Gaps between the Plasma Cell and the Neoplastic Niche. J. Oncol. 2020, 2020, 1-16. [CrossRef]

82. Noonan, K.; Borrello, I. The immune microenvironment of myeloma. Cancer Microenviron. Off. J. Int. Cancer Microenviron. Soc. 2011, 4, 313-323. [CrossRef] [PubMed]

83. Saltarella, I.; Desantis, V.; Melaccio, A.; Solimando, A.G.; Lamanuzzi, A.; Ria, R.; Storlazzi, C.T.; Mariggiò, M.A.; Vacca, A.; Frassanito, M.A. Mechanisms of Resistance to Anti-CD38 Daratumumab in Multiple Myeloma. Cells 2020, 9, 167. [CrossRef] [PubMed]

84. Moschetta, M.; Basile, A.; Ferrucci, A.; Frassanito, M.A.; Rao, L.; Ria, R.; Solimando, A.G.; Giuliani, N.; Boccarelli, A.; Fumarola, F.; et al. Novel targeting of phospho-cMET overcomes drug resistance and induces antitumor activity in multiple myeloma. Clin. Cancer Res. Off. J. Am. Assoc. Cancer Res. 2013, 19, 4371-4382. [CrossRef] [PubMed]

85. Ferrucci, A.; Moschetta, M.; Frassanito, M.A.; Berardi, S.; Catacchio, I.; Ria, R.; Racanelli, V.; Caivano, A.; Solimando, A.G.; Vergara, D.; et al. A HGF/cMET autocrine loop is operative in multiple myeloma bone marrow endothelial cells and may represent a novel therapeutic target. Clin. Cancer Res. Off. J. Am. Assoc. Cancer Res. 2014, 20, 5796-5807. [CrossRef]

86. Frassanito, M.A.; Desantis, V.; Di Marzo, L.; Craparotta, I.; Beltrame, L.; Marchini, S.; Annese, T.; Visino, F.; Arciuli, M.; Saltarella, I.; et al. Bone marrow fibroblasts overexpress miR-27b and miR-214 in step with multiple myeloma progression, dependent on tumour cell-derived exosomes: Myeloma cell-derived exosomes and fibroblast miRNA expression. J. Pathol. 2019, 247, 241-253. [CrossRef]

87. Desantis, V.; Saltarella, I.; Lamanuzzi, A.; Melaccio, A.; Solimando, A.G.; Mariggiò, M.A.; Racanelli, V.; Paradiso, A.; Vacca, A.; Frassanito, M.A. MicroRNAs-Based Nano-Strategies as New Therapeutic Approach in Multiple Myeloma to Overcome Disease Progression and Drug Resistance. Int. J. Mol. Sci. 2020, 21, 3084. [CrossRef]

88. Solimando, A.G.; Da Via', M.C.; Leone, P.; Croci, G.; Borrelli, P.; Tabares Gaviria, P.; Brandl, A.; Di Lernia, G.; Bianchi, F.P.; Tafuri, S.; et al. Adhesion-Mediated Multiple Myeloma (MM) Disease Progression: Junctional Adhesion Molecule a Enhances Angiogenesis and Multiple Myeloma Dissemination and Predicts Poor Survival. Blood 2019, 134, 855. [CrossRef]

89. Saadatmand, S.; de Kruijf, E.M.; Sajet, A.; Dekker-Ensink, N.G.; van Nes, J.G.H.; Putter, H.; Smit, V.T.H.B.M.; van de Velde, C.J.H.; Liefers, G.J.; Kuppen, P.J.K. Expression of cell adhesion molecules and prognosis in breast cancer. Br. J. Surg. 2013, 100, 252-260. [CrossRef]

90. Moh, M.C.; Shen, S. The roles of cell adhesion molecules in tumor suppression and cell migration: A new paradox. Cell Adhes. Migr. 2009, 3, 334-336. [CrossRef]

91. Kelly, K.R.; Espitia, C.M.; Zhao, W.; Wendlandt, E.; Tricot, G.; Zhan, F.; Carew, J.S.; Nawrocki, S.T. Junctional adhesion molecule-A is overexpressed in advanced multiple myeloma and determines response to oncolytic reovirus. Oncotarget 2015, 6, 41275-41289. [CrossRef] 
92. Teoh, G.; Anderson, K.C. Interaction of Tumor and Host Cells With Adhesion and Extracellular Matrix Molecules in the Development of Multiple Myeloma. Hematol. Oncol. Clin. N. Am. 1997, 11, 27-42. [CrossRef]

93. Braunstein, M.J.; Campagne, F.; Mukherjee, P.; Carrasco, D.R.; Sukhdeo, K.; Protopopov, A.; Anderson, K.C.; Batuman, O. Genome-Wide Profiling of Endothelial Progenitor Cells in Multiple Myeloma: Disease-Relevant Pathways and Overlaps with Common Cancer Biomarkers. Blood 2008, 112, 626. [CrossRef]

94. Gautier, L.; Cope, L.; Bolstad, B.M.; Irizarry, R.A. affy-analysis of Affymetrix GeneChip data at the probe level. Bioinformatics 2004, 20, 307-315. [CrossRef] [PubMed]

95. Ritchie, M.E.; Phipson, B.; Wu, D.; Hu, Y.; Law, C.W.; Shi, W.; Smyth, G.K. limma powers differential expression analyses for RNA-sequencing and microarray studies. Nucleic Acids Res. 2015, 43, e47. [CrossRef] [PubMed]

96. Gil Marques, F.; Poli, E.; Malaquias, J.; Carvalho, T.; Portêlo, A.; Ramires, A.; Aldeia, F.; Ribeiro, R.M.; Vitorino, E.; Diegues, I.; et al. Low doses of ionizing radiation activate endothelial cells and induce angiogenesis in peritumoral tissues. Radiother. Oncol. J. Eur. Soc. Ther. Radiol. Oncol. 2019, 141, 256-261. [CrossRef]

97. Galili, T. dendextend: An R package for visualizing, adjusting and comparing trees of hierarchical clustering. Bioinformatics (Oxf. Engl.) 2015, 31, 3718-3720. [CrossRef]

98. Zeileis, A.; Fisher, J.C.; Hornik, K.; Ihaka, R.; McWhite, C.D.; Murrell, P.; Stauffer, R.; Wilke, C.O. Colorspace: A Toolbox for Manipulating and Assessing Colors and Palettes. arXiv 2019, arXiv:190306490.

99. Wickham, H. Ggplot2: Elegant Graphics for Data Analysis; Use R! Springer: Dordrecht, The Netherlands, 2009; ISBN 978-0-387-98141-3.

100. Abe, M. Targeting the interplay between myeloma cells and the bone marrow microenvironment in myeloma. Int. J. Hematol. 2011, 94, 334-343. [CrossRef]

101. Leich, E.; Weißbach, S.; Klein, H.-U.; Grieb, T.; Pischimarov, J.; Stühmer, T.; Chatterjee, M.; Steinbrunn, T.; Langer, C.; Eilers, M.; et al. Multiple myeloma is affected by multiple and heterogeneous somatic mutations in adhesion- and receptor tyrosine kinase signaling molecules. Blood Cancer J. 2013, 3, e102. [CrossRef]

102. Jridi, I.; Catacchio, I.; Majdoub, H.; Shahbazzadeh, D.; El Ayeb, M.; Frassanito, M.A.; Solimando, A.G.; Ribatti, D.; Vacca, A.; Borchani, L. The small subunit of Hemilipin2, a new heterodimeric phospholipase A2 from Hemiscorpius lepturus scorpion venom, mediates the antiangiogenic effect of the whole protein. Toxicon Off. J. Int. Soc. Toxinology 2017, 126, 38-46. [CrossRef]

103. Flati, V.; Pastore, L.I.; Griffioen, A.W.; Satijn, S.; Toniato, E.; D’Alimonte, I.; Laglia, E.; Marchetti, P.; Gulino, A.; Martinotti, S. Endothelial cell anergy is mediated by bFGF through the sustained activation of p38-MAPK and NF-kappaB inhibition. Int. J. Immunopathol. Pharmacol. 2006, 19, 761-773. [CrossRef] [PubMed]

104. Peddibhotla, S.S.D.; Brinkmann, B.F.; Kummer, D.; Tuncay, H.; Nakayama, M.; Adams, R.H.; Gerke, V.; Ebnet, K. Tetraspanin CD9 links junctional adhesion molecule-A to $\alpha \mathrm{v} \beta 3$ integrin to mediate basic fibroblast growth factor-specific angiogenic signaling. Mol. Biol. Cell 2013, 24, 933-944. [CrossRef] [PubMed]

105. Griffioen, A.W.; Damen, C.A.; Mayo, K.H.; Barendsz-Janson, A.F.; Martinotti, S.; Blijham, G.H.; Groenewegen, G. Angiogenesis inhibitors overcome tumor induced endothelial cell anergy. Int. J. Cancer 1999, 80, 315-319. [CrossRef]

106. Dirkx, A.E.M.; Oude Egbrink, M.G.A.; Kuijpers, M.J.E.; van der Niet, S.T.; Heijnen, V.V.T.; Bouma-ter Steege, J.C.A.; Wagstaff, J.; Griffioen, A.W. Tumor angiogenesis modulates leukocyte-vessel wall interactions in vivo by reducing endothelial adhesion molecule expression. Cancer Res. 2003, 63, 2322-2329. [PubMed]

107. Cook-Mills, J.M.; Deem, T.L. Active participation of endothelial cells in inflammation. J. Leukoc. Biol. 2005, 77, 487-495. [CrossRef] [PubMed]

108. Lauko, A.; Mu, Z.; Gutmann, D.H.; Naik, U.P.; Lathia, J.D. Junctional Adhesion Molecules in Cancer: A Paradigm for the Diverse Functions of Cell-Cell Interactions in Tumor Progression. Cancer Res. 2020. [CrossRef]

109. Huang, H.; Langenkamp, E.; Georganaki, M.; Loskog, A.; Fuchs, P.F.; Dieterich, L.C.; Kreuger, J.; Dimberg, A. VEGF suppresses T-lymphocyte infiltration in the tumor microenvironment through inhibition of NF-kB-induced endothelial activation. FASEB J. Off. Publ. Fed. Am. Soc. Exp. Biol. 2015, 29, 227-238. [CrossRef] [PubMed]

110. Lazennec, G.; Richmond, A. Chemokines and chemokine receptors: New insights into cancer-related inflammation. Trends Mol. Med. 2010, 16, 133-144. [CrossRef]

111. Lanitis, E.; Irving, M.; Coukos, G. Targeting the tumor vasculature to enhance T cell activity. Curr. Opin. Immunol. 2015, 33, 55-63. [CrossRef] 
112. Georganaki, M.; van Hooren, L.; Dimberg, A. Vascular Targeting to Increase the Efficiency of Immune Checkpoint Blockade in Cancer. Front. Immunol. 2018, 9, 3081. [CrossRef]

113. Salik, B.; Smyth, M.J.; Nakamura, K. Targeting immune checkpoints in hematological malignancies. J. Hematol. Oncol. J Hematol. Oncol. 2020, 13, 111. [CrossRef] [PubMed]

114. Georganaki, M.; Ramachandran, M.; Tuit, S.; Núñez, N.G.; Karampatzakis, A.; Fotaki, G.; van Hooren, L.; Huang, H.; Lugano, R.; Ulas, T.; et al. Tumor endothelial cell up-regulation of IDO1 is an immunosuppressive feed-back mechanism that reduces the response to CD40-stimulating immunotherapy. Oncoimmunology 2020, 9, 1730538. [CrossRef] [PubMed]

115. Shiao, S.L.; Kirkiles-Smith, N.C.; Shepherd, B.R.; McNiff, J.M.; Carr, E.J.; Pober, J.S. Human effector memory CD4+ T cells directly recognize allogeneic endothelial cells in vitro and in vivo. J. Immunol. Baltim. Md 1950 2007, 179, 4397-4404. [CrossRef] [PubMed]

116. Kochan, G.; Escors, D.; Breckpot, K.; Guerrero-Setas, D. Role of non-classical MHC class I molecules in cancer immunosuppression. Oncoimmunology 2013, 2, e26491. [CrossRef]

117. Goveia, J.; Rohlenova, K.; Taverna, F.; Treps, L.; Conradi, L.-C.; Pircher, A.; Geldhof, V.; de Rooij, L.P.M.H.; Kalucka, J.; Sokol, L.; et al. An Integrated Gene Expression Landscape Profiling Approach to Identify Lung Tumor Endothelial Cell Heterogeneity and Angiogenic Candidates. Cancer Cell 2020, 37, 21-36.e13. [CrossRef]

118. Barthel, S.R.; Gavino, J.D.; Descheny, L.; Dimitroff, C.J. Targeting selectins and selectin ligands in inflammation and cancer. Expert Opin. Ther. Targets 2007, 11, 1473-1491. [CrossRef]

119. Kong, D.-H.; Kim, Y.K.; Kim, M.R.; Jang, J.H.; Lee, S. Emerging Roles of Vascular Cell Adhesion Molecule-1 (VCAM-1) in Immunological Disorders and Cancer. Int. J. Mol. Sci. 2018, 19, 1057. [CrossRef]

120. Delfortrie, S.; Pinte, S.; Mattot, V.; Samson, C.; Villain, G.; Caetano, B.; Lauridant-Philippin, G.; Baranzelli, M.-C.; Bonneterre, J.; Trottein, F.; et al. Egfl7 promotes tumor escape from immunity by repressing endothelial cell activation. Cancer Res. 2011, 71, 7176-7186. [CrossRef]

121. Pannier, D.; Philippin-Lauridant, G.; Baranzelli, M.-C.; Bertin, D.; Bogart, E.; Delprat, V.; Villain, G.; Mattot, V.; Bonneterre, J.; Soncin, F. High expression levels of egfl7 correlate with low endothelial cell activation in peritumoral vessels of human breast cancer. Oncol. Lett. 2016, 12, 1422-1428. [CrossRef]

122. Salama, Y.; Heida, A.H.; Yokoyama, K.; Takahashi, S.; Hattori, K.; Heissig, B. The EGFL7-ITGB3-KLF2 axis enhances survival of multiple myeloma in preclinical models. Blood Adv. 2020, 4, 1021-1037. [CrossRef]

123. De Sanctis, F.; Ugel, S.; Facciponte, J.; Facciabene, A. The dark side of tumor-associated endothelial cells. Semin. Immunol. 2018, 35, 35-47. [CrossRef] [PubMed]

124. Zhang, B.; Karrison, T.; Rowley, D.A.; Schreiber, H. IFN- $\gamma-$ and TNF-dependent bystander eradication of antigen-loss variants in established mouse cancers. J. Clin. Investig. 2008, 118, 1398-1404. [CrossRef] [PubMed]

125. Enzler, T.; Gillessen, S.; Manis, J.P.; Ferguson, D.; Fleming, J.; Alt, F.W.; Mihm, M.; Dranoff, G. Deficiencies of GM-CSF and interferon gamma link inflammation and cancer. J. Exp. Med. 2003, 197, 1213-1219. [CrossRef] [PubMed]

126. List, A.F. Vascular endothelial growth factor signaling pathway as an emerging target in hematologic malignancies. Oncologist 2001, 6 (Suppl. 5), 24-31. [CrossRef]

127. Josephs, S.F.; Ichim, T.E.; Prince, S.M.; Kesari, S.; Marincola, F.M.; Escobedo, A.R.; Jafri, A. Unleashing endogenous TNF-alpha as a cancer immunotherapeutic. J. Transl. Med. 2018, 16, 242. [CrossRef]

128. Ray, A.; Song, Y.; Du, T.; Chauhan, D.; Anderson, K.C. Preclinical validation of Alpha-Enolase (ENO1) as a novel immunometabolic target in multiple myeloma. Oncogene 2020, 39, 2786-2796. [CrossRef]

129. Maishi, N.; Ohba, Y.; Akiyama, K.; Ohga, N.; Hamada, J.-I.; Nagao-Kitamoto, H.; Alam, M.T.; Yamamoto, K.; Kawamoto, T.; Inoue, N.; et al. Tumour endothelial cells in high metastatic tumours promote metastasis via epigenetic dysregulation of biglycan. Sci. Rep. 2016, 6, 28039. [CrossRef]

130. Lund, A.W.; Wagner, M.; Fankhauser, M.; Steinskog, E.S.; Broggi, M.A.; Spranger, S.; Gajewski, T.F.; Alitalo, K.; Eikesdal, H.P.; Wiig, H.; et al. Lymphatic vessels regulate immune microenvironments in human and murine melanoma. J. Clin. Investig. 2016, 126, 3389-3402. [CrossRef]

131. De Caterina, R.; Libby, P.; Peng, H.B.; Thannickal, V.J.; Rajavashisth, T.B.; Gimbrone, M.A.; Shin, W.S.; Liao, J.K. Nitric oxide decreases cytokine-induced endothelial activation. Nitric oxide selectively reduces endothelial expression of adhesion molecules and proinflammatory cytokines. J. Clin. Investig. 1995, 96, 60-68. [CrossRef] 
132. Bouzin, C.; Brouet, A.; De Vriese, J.; Dewever, J.; Feron, O. Effects of vascular endothelial growth factor on the lymphocyte-endothelium interactions: Identification of caveolin-1 and nitric oxide as control points of endothelial cell anergy. J. Immunol. 2007, 178, 1505-1511. [CrossRef]

133. Secchiero, P.; Gonelli, A.; Celeghini, C.; Mirandola, P.; Guidotti, L.; Visani, G.; Capitani, S.; Zauli, G. Activation of the nitric oxide synthase pathway represents a key component of tumor necrosis factor-related apoptosis-inducing ligand-mediated cytotoxicity on hematologic malignancies. Blood 2001, 98, 2220-2228. [CrossRef] [PubMed]

134. Xu, W.; Liu, L.Z.; Loizidou, M.; Ahmed, M.; Charles, I.G. The role of nitric oxide in cancer. Cell Res. 2002, 12, 311-320. [CrossRef]

135. Gooden, M.; Lampen, M.; Jordanova, E.S.; Leffers, N.; Trimbos, J.B.; van der Burg, S.H.; Nijman, H.; van Hall, T. HLA-E expression by gynecological cancers restrains tumor-infiltrating CD8+ T lymphocytes. Proc. Natl. Acad. Sci. USA 2011, 108, 10656-10661. [CrossRef] [PubMed]

136. Rossi, E.; Sanz-Rodriguez, F.; Eleno, N.; Düwell, A.; Blanco, F.J.; Langa, C.; Botella, L.M.; Cabañas, C.; Lopez-Novoa, J.M.; Bernabeu, C. Endothelial endoglin is involved in inflammation: Role in leukocyte adhesion and transmigration. Blood 2013, 121, 403-415. [CrossRef] [PubMed]

137. Stalin, J.; Nollet, M.; Garigue, P.; Fernandez, S.; Vivancos, L.; Essaadi, A.; Muller, A.; Bachelier, R.; Foucault-Bertaud, A.; Fugazza, L.; et al. Targeting soluble CD146 with a neutralizing antibody inhibits vascularization, growth and survival of CD146-positive tumors. Oncogene 2016, 35, 5489-5500. [CrossRef]

138. Leone, P.; Solimando, A.G.; Malerba, E.; Fasano, R.; Buonavoglia, A.; Pappagallo, F.; De Re, V.; Argentiero, A.; Silvestris, N.; Vacca, A.; et al. Actors on the Scene: Immune Cells in the Myeloma Niche. Front. Oncol. 2020, 10, 599098. [CrossRef]

139. Scavelli, C.; Weber, E.; Aglianò, M.; Cirulli, T.; Nico, B.; Vacca, A.; Ribatti, D. Lymphatics at the crossroads of angiogenesis and lymphangiogenesis. J. Anat. 2004, 204, 433-449. [CrossRef]

140. Ribatti, D.; Nico, B.; Crivellato, E.; Vacca, A. The structure of the vascular network of tumors. Cancer Lett. 2007, 248, 18-23. [CrossRef]

141. Hunter, M.C.; Teijeira, A.; Halin, C. T Cell Trafficking through Lymphatic Vessels. Front. Immunol. 2016, 7. [CrossRef]

142. Eklund, L.; Bry, M.; Alitalo, K. Mouse models for studying angiogenesis and lymphangiogenesis in cancer. Mol. Oncol. 2013, 7, 259-282. [CrossRef]

143. Tomura, M.; Yoshida, N.; Tanaka, J.; Karasawa, S.; Miwa, Y.; Miyawaki, A.; Kanagawa, O. Monitoring cellular movement in vivo with photoconvertible fluorescence protein "Kaede" transgenic mice. Proc. Natl. Acad. Sci. USA 2008, 105, 10871-10876. [CrossRef] [PubMed]

144. Steele, M.M.; Churchill, M.J.; Breazeale, A.P.; Lane, R.S.; Nelson, N.A.; Lund, A.W. Quantifying Leukocyte Egress via Lymphatic Vessels from Murine Skin and Tumors. J. Vis. Exp. 2019, 58704. [CrossRef] [PubMed]

145. Flores-Toro, J.A.; Luo, D.; Gopinath, A.; Sarkisian, M.R.; Campbell, J.J.; Charo, I.F.; Singh, R.; Schall, T.J.; Datta, M.; Jain, R.K.; et al. CCR2 inhibition reduces tumor myeloid cells and unmasks a checkpoint inhibitor effect to slow progression of resistant murine gliomas. Proc. Natl. Acad. Sci. USA 2020, 117, 1129-1138. [CrossRef] [PubMed]

146. Gibellini, L.; De Biasi, S.; Porta, C.; Lo Tartaro, D.; Depenni, R.; Pellacani, G.; Sabbatini, R.; Cossarizza, A. Single-Cell Approaches to Profile the Response to Immune Checkpoint Inhibitors. Front. Immunol. 2020, 11, 490. [CrossRef]

147. Progatzky, F.; Dallman, M.J.; Lo Celso, C. From seeing to believing: Labelling strategies for in vivo cell-tracking experiments. Interface Focus 2013, 3, 20130001. [CrossRef]

148. Ito, K.; Morimoto, J.; Kihara, A.; Matsui, Y.; Kurotaki, D.; Kanayama, M.; Simmons, S.; Ishii, M.; Sheppard, D.; Takaoka, A.; et al. Integrin $\alpha 9$ on lymphatic endothelial cells regulates lymphocyte egress. Proc. Natl. Acad. Sci. USA 2014, 111, 3080-3085. [CrossRef]

149. Schwab, S.R.; Cyster, J.G. Finding a way out: Lymphocyte egress from lymphoid organs. Nat. Immunol. 2007, 8, 1295-1301. [CrossRef]

150. Torcellan, T.; Hampton, H.R.; Bailey, J.; Tomura, M.; Brink, R.; Chtanova, T. In vivo photolabeling of tumor-infiltrating cells reveals highly regulated egress of T-cell subsets from tumors. Proc. Natl. Acad. Sci. USA 2017, 114, 5677-5682. [CrossRef] 
151. Duhen, T.; Duhen, R.; Montler, R.; Moses, J.; Moudgil, T.; de Miranda, N.F.; Goodall, C.P.; Blair, T.C.; Fox, B.A.; McDermott, J.E.; et al. Co-expression of CD39 and CD103 identifies tumor-reactive CD8 T cells in human solid tumors. Nat. Commun. 2018, 9, 2724. [CrossRef]

152. Condeelis, J.; Weissleder, R. In vivo imaging in cancer. Cold Spring Harb. Perspect. Biol. 2010, 2, a003848. [CrossRef]

153. Vakoc, B.J.; Lanning, R.M.; Tyrrell, J.A.; Padera, T.P.; Bartlett, L.A.; Stylianopoulos, T.; Munn, L.L.; Tearney, G.J.; Fukumura, D.; Jain, R.K.; et al. Three-dimensional microscopy of the tumor microenvironment in vivo using optical frequency domain imaging. Nat. Med. 2009, 15, 1219-1223. [CrossRef] [PubMed]

154. Antonio, G.; Oronzo, B.; Vito, L.; Angela, C.; Antonel-la, A.; Roberto, C.; Giovanni, S.A.; Antonella, L. Immune system and bone microenvironment: Rationale for targeted cancer therapies. Oncotarget 2020, 11. [CrossRef] [PubMed]

155. Jung, K.; Heishi, T.; Khan, O.F.; Kowalski, P.S.; Incio, J.; Rahbari, N.N.; Chung, E.; Clark, J.W.; Willett, C.G.; Luster, A.D.; et al. Ly6Clo monocytes drive immunosuppression and confer resistance to anti-VEGFR2 cancer therapy. J. Clin. Investig. 2017, 127, 3039-3051. [CrossRef] [PubMed]

156. Bruns, O.T.; Bischof, T.S.; Harris, D.K.; Franke, D.; Shi, Y.; Riedemann, L.; Bartelt, A.; Jaworski, F.B.; Carr, J.A.; Rowlands, C.J.; et al. Next-generation in vivo optical imaging with short-wave infrared quantum dots. Nat. Biomed. Eng. 2017, 1, 56. [CrossRef]

157. Brown, E.B.; Campbell, R.B.; Tsuzuki, Y.; Xu, L.; Carmeliet, P.; Fukumura, D.; Jain, R.K. In vivo measurement of gene expression, angiogenesis and physiological function in tumors using multiphoton laser scanning microscopy. Nat. Med. 2001, 7, 864-868. [CrossRef]

158. Kirkpatrick, N.D.; Chung, E.; Cook, D.C.; Han, X.; Gruionu, G.; Liao, S.; Munn, L.L.; Padera, T.P.; Fukumura, D.; Jain, R.K. Video-rate resonant scanning multiphoton microscopy: An emerging technique for intravital imaging of the tumor microenvironment. Intravital 2012, 1. [CrossRef]

159. Yuan, F.; Salehi, H.A.; Boucher, Y.; Vasthare, U.S.; Tuma, R.F.; Jain, R.K. Vascular permeability and microcirculation of gliomas and mammary carcinomas transplanted in rat and mouse cranial windows. Cancer Res. 1994, 54, 4564-4568.

160. Fukumura, D.; Kloepper, J.; Amoozgar, Z.; Duda, D.G.; Jain, R.K. Enhancing cancer immunotherapy using antiangiogenics: Opportunities and challenges. Nat. Rev. Clin. Oncol. 2018, 15, 325-340. [CrossRef]

161. Martin, J.D.; Fukumura, D.; Duda, D.G.; Boucher, Y.; Jain, R.K. Reengineering the Tumor Microenvironment to Alleviate Hypoxia and Overcome Cancer Heterogeneity. Cold Spring Harb. Perspect. Med. 2016, 6. [CrossRef]

162. Li, J.; Chekkoury, A.; Prakash, J.; Glasl, S.; Vetschera, P.; Koberstein-Schwarz, B.; Olefir, I.; Gujrati, V.; Omar, M.; Ntziachristos, V. Spatial heterogeneity of oxygenation and haemodynamics in breast cancer resolved in vivo by conical multispectral optoacoustic mesoscopy. Light Sci. Appl. 2020, 9, 57. [CrossRef]

163. Pires, I.M.; Bencokova, Z.; Milani, M.; Folkes, L.K.; Li, J.-L.; Stratford, M.R.; Harris, A.L.; Hammond, E.M. Effects of acute versus chronic hypoxia on DNA damage responses and genomic instability. Cancer Res. 2010, 70, 925-935. [CrossRef] [PubMed]

164. Eales, K.L.; Hollinshead, K.E.R.; Tennant, D.A. Hypoxia and metabolic adaptation of cancer cells. Oncogenesis 2016, 5, e190. [CrossRef] [PubMed]

165. Zhang, L.; Huang, G.; Li, X.; Zhang, Y.; Jiang, Y.; Shen, J.; Liu, J.; Wang, Q.; Zhu, J.; Feng, X.; et al. Hypoxia induces epithelial-mesenchymal transition via activation of SNAI1 by hypoxia-inducible factor $-1 \alpha$ in hepatocellular carcinoma. BMC Cancer 2013, 13, 108. [CrossRef] [PubMed]

166. Heddleston, J.M.; Li, Z.; McLendon, R.E.; Hjelmeland, A.B.; Rich, J.N. The hypoxic microenvironment maintains glioblastoma stem cells and promotes reprogramming towards a cancer stem cell phenotype. Cell Cycle 2009, 8, 3274-3284. [CrossRef]

167. Azad, M.B.; Chen, Y.; Henson, E.S.; Cizeau, J.; McMillan-Ward, E.; Israels, S.J.; Gibson, S.B. Hypoxia induces autophagic cell death in apoptosis-competent cells through a mechanism involving BNIP3. Autophagy 2008, 4, 195-204. [CrossRef]

168. Di Lernia, G.; Leone, P.; Solimando, A.G.; Buonavoglia, A.; Saltarella, I.; Ria, R.; Ditonno, P.; Silvestris, N.; Crudele, L.; Vacca, A.; et al. Bortezomib Treatment Modulates Autophagy in Multiple Myeloma. J. Clin. Med. 2020, 9, 552. [CrossRef]

169. Graham, K.; Unger, E. Overcoming tumor hypoxia as a barrier to radiotherapy, chemotherapy and immunotherapy in cancer treatment. Int. J. Nanomedicine 2018, 13, 6049-6058. [CrossRef]

170. Shannon, A.M.; Bouchier-Hayes, D.J.; Condron, C.M.; Toomey, D. Tumour hypoxia, chemotherapeutic resistance and hypoxia-related therapies. Cancer Treat. Rev. 2003, 29, 297-307. [CrossRef] 
171. Brunetti, O.; Gnoni, A.; Licchetta, A.; Longo, V.; Calabrese, A.; Argentiero, A.; Delcuratolo, S.; Solimando, A.G.; Casadei-Gardini, A.; Silvestris, N. Predictive and Prognostic Factors in HCC Patients Treated with Sorafenib. Med. Kaunas Lith. 2019, 55, 707. [CrossRef]

172. Schaaf, M.B.; Garg, A.D.; Agostinis, P. Defining the role of the tumor vasculature in antitumor immunity and immunotherapy. Cell Death Dis. 2018, 9, 115. [CrossRef]

173. Longo, V.; Brunetti, O.; Gnoni, A.; Licchetta, A.; Delcuratolo, S.; Memeo, R.; Solimando, A.G.; Argentiero, A. Emerging role of Immune Checkpoint Inhibitors in Hepatocellular Carcinoma. Med. Kaunas Lith. 2019, 55, 698. [CrossRef] [PubMed]

174. Chouaib, S.; Messai, Y.; Couve, S.; Escudier, B.; Hasmim, M.; Noman, M.Z. Hypoxia promotes tumor growth in linking angiogenesis to immune escape. Front. Immunol. 2012, 3, 21. [CrossRef] [PubMed]

175. Solimando, A.G.; Da Vià, M.C.; Cicco, S.; Leone, P.; Di Lernia, G.; Giannico, D.; Desantis, V.; Frassanito, M.A.; Morizio, A.; Delgado Tascon, J.; et al. High-Risk Multiple Myeloma: Integrated Clinical and Omics Approach Dissects the Neoplastic Clone and the Tumor Microenvironment. J. Clin. Med. 2019, 8, 997. [CrossRef] [PubMed]

176. Michiels, C. Physiological and pathological responses to hypoxia. Am. J. Pathol. 2004, 164, 1875-1882. [CrossRef]

177. Brahimi-Horn, M.C.; Chiche, J.; Pouysségur, J. Hypoxia and cancer. J. Mol. Med. 2007, 85, 1301-1307. [CrossRef]

178. Luoto, K.R.; Kumareswaran, R.; Bristow, R.G. Tumor hypoxia as a driving force in genetic instability. Genome Integr. 2013, 4, 5. [CrossRef]

179. Gilkes, D.M.; Semenza, G.L.; Wirtz, D. Hypoxia and the extracellular matrix: Drivers of tumour metastasis. Nat. Rev. Cancer 2014, 14, 430-439. [CrossRef]

180. Rockwell, S.; Dobrucki, I.T.; Kim, E.Y.; Marrison, S.T.; Vu, V.T. Hypoxia and radiation therapy: Past history, ongoing research, and future promise. Curr. Mol. Med. 2009, 9, 442-458. [CrossRef]

181. Feng, J.; Byrne, N.M.; Al Jamal, W.; Coulter, J.A. Exploiting Current Understanding of Hypoxia Mediated Tumour Progression for Nanotherapeutic Development. Cancers 2019, 11, 1989. [CrossRef]

182. Koumenis, C.; Wouters, B.G. “Translating” tumor hypoxia: Unfolded protein response (UPR)-dependent and UPR-independent pathways. Mol. Cancer Res. MCR 2006, 4, 423-436. [CrossRef]

183. Wilson, W.R.; Hay, M.P. Targeting hypoxia in cancer therapy. Nat. Rev. Cancer 2011, 11, $393-410$. [CrossRef] [PubMed]

184. Samples, J.; Willis, M.; Klauber-Demore, N. Targeting angiogenesis and the tumor microenvironment. Surg. Oncol. Clin. N. Am. 2013, 22, 629-639. [CrossRef] [PubMed]

185. Desantis, V.; Frassanito, M.A.; Tamma, R.; Saltarella, I.; Di Marzo, L.; Lamanuzzi, A.; Solimando, A.G.; Ruggieri, S.; Annese, T.; Nico, B.; et al. Rhu-Epo down-regulates pro-tumorigenic activity of cancer-associated fibroblasts in multiple myeloma. Ann. Hematol. 2018, 97, 1251-1258. [CrossRef] [PubMed]

186. Lugano, R.; Ramachandran, M.; Dimberg, A. Tumor angiogenesis: Causes, consequences, challenges and opportunities. Cell. Mol. Life Sci. 2020, 77, 1745-1770. [CrossRef]

187. Rao, L.; Giannico, D.; Leone, P.; Solimando, A.G.; Maiorano, E.; Caporusso, C.; Duda, L.; Tamma, R.; Mallamaci, R.; Susca, N.; et al. HB-EGF-EGFR Signaling in Bone Marrow Endothelial Cells Mediates Angiogenesis Associated with Multiple Myeloma. Cancers 2020, 12, 173. [CrossRef]

188. Winkler, F.; Kozin, S.V.; Tong, R.T.; Chae, S.-S.; Booth, M.F.; Garkavtsev, I.; Xu, L.; Hicklin, D.J.; Fukumura, D.; di Tomaso, E.; et al. Kinetics of vascular normalization by VEGFR2 blockade governs brain tumor response to radiation: Role of oxygenation, angiopoietin-1, and matrix metalloproteinases. Cancer Cell 2004, 6, 553-563. [CrossRef]

189. Goel, S.; Duda, D.G.; Xu, L.; Munn, L.L.; Boucher, Y.; Fukumura, D.; Jain, R.K. Normalization of the vasculature for treatment of cancer and other diseases. Physiol. Rev. 2011, 91, 1071-1121. [CrossRef]

190. Gerald, D.; Chintharlapalli, S.; Augustin, H.G.; Benjamin, L.E. Angiopoietin-2: An Attractive Target for Improved Antiangiogenic Tumor Therapy. Cancer Res. 2013, 73, 1649-1657. [CrossRef]

191. Rao, L.; De Veirman, K.; Giannico, D.; Saltarella, I.; Desantis, V.; Frassanito, M.A.; Solimando, A.G.; Ribatti, D.; Prete, M.; Harstrick, A.; et al. Targeting angiogenesis in multiple myeloma by the VEGF and HGF blocking DARPin®protein MP0250: A preclinical study. Oncotarget 2018, 9, 13366-13381. [CrossRef]

192. Chae, S.-S.; Kamoun, W.S.; Farrar, C.T.; Kirkpatrick, N.D.; Niemeyer, E.; de Graaf, A.M.A.; Sorensen, A.G.; Munn, L.L.; Jain, R.K.; Fukumura, D. Angiopoietin-2 Interferes with Anti-VEGFR2-Induced Vessel Normalization and Survival Benefit in Mice Bearing Gliomas. Clin. Cancer Res. 2010, 16, 3618-3627. [CrossRef] 
193. Peterson, T.E.; Kirkpatrick, N.D.; Huang, Y.; Farrar, C.T.; Marijt, K.A.; Kloepper, J.; Datta, M.; Amoozgar, Z.; Seano, G.; Jung, K.; et al. Dual inhibition of Ang-2 and VEGF receptors normalizes tumor vasculature and prolongs survival in glioblastoma by altering macrophages. Proc. Natl. Acad. Sci. USA 2016, 113, 4470-4475. [CrossRef] [PubMed]

194. Facciabene, A.; Motz, G.T.; Coukos, G. T-regulatory cells: Key players in tumor immune escape and angiogenesis. Cancer Res. 2012, 72, 2162-2171. [CrossRef] [PubMed]

195. Liu, C.; Workman, C.J.; Vignali, D.A.A. Targeting regulatory T cells in tumors. FEBS J. 2016, 283, $2731-2748$. [CrossRef] [PubMed]

196. Maenhout, S.K.; Thielemans, K.; Aerts, J.L. Location, location, location: Functional and phenotypic heterogeneity between tumor-infiltrating and non-infiltrating myeloid-derived suppressor cells. Oncoimmunology 2014, 3, e956579. [CrossRef] [PubMed]

197. Palazon, A.; Tyrakis, P.A.; Macias, D.; Veliça, P.; Rundqvist, H.; Fitzpatrick, S.; Vojnovic, N.; Phan, A.T.; Loman, N.; Hedenfalk, I.; et al. An HIF-1 $\alpha$ /VEGF-A Axis in Cytotoxic T Cells Regulates Tumor Progression. Cancer Cell 2017, 32, 669-683.e5. [CrossRef] [PubMed]

198. Jain, R.K. Antiangiogenesis strategies revisited: From starving tumors to alleviating hypoxia. Cancer Cell 2014, 26, 605-622. [CrossRef] [PubMed]

199. Rolny, C.; Mazzone, M.; Tugues, S.; Laoui, D.; Johansson, I.; Coulon, C.; Squadrito, M.L.; Segura, I.; Li, X.; Knevels, E.; et al. HRG inhibits tumor growth and metastasis by inducing macrophage polarization and vessel normalization through downregulation of PlGF. Cancer Cell 2011, 19, 31-44. [CrossRef]

200. Chang, A.L.; Miska, J.; Wainwright, D.A.; Dey, M.; Rivetta, C.V.; Yu, D.; Kanojia, D.; Pituch, K.C.; Qiao, J.; Pytel, P.; et al. CCL2 Produced by the Glioma Microenvironment Is Essential for the Recruitment of Regulatory T Cells and Myeloid-Derived Suppressor Cells. Cancer Res. 2016, 76, 5671-5682. [CrossRef]

201. Hendry, S.A.; Farnsworth, R.H.; Solomon, B.; Achen, M.G.; Stacker, S.A.; Fox, S.B. The Role of the Tumor Vasculature in the Host Immune Response: Implications for Therapeutic Strategies Targeting the Tumor Microenvironment. Front. Immunol. 2016, 7, 621. [CrossRef]

202. Zhang, Y.; Zhang, Z. The history and advances in cancer immunotherapy: Understanding the characteristics of tumor-infiltrating immune cells and their therapeutic implications. Cell. Mol. Immunol. 2020, 17, 807-821. [CrossRef]

203. Conley, S.J.; Gheordunescu, E.; Kakarala, P.; Newman, B.; Korkaya, H.; Heath, A.N.; Clouthier, S.G.; Wicha, M.S. Antiangiogenic agents increase breast cancer stem cells via the generation of tumor hypoxia. Proc. Natl. Acad. Sci. USA 2012, 109, 2784-2789. [CrossRef] [PubMed]

204. Jain, R.K. Normalizing tumor microenvironment to treat cancer: Bench to bedside to biomarkers. J. Clin. Oncol. Off. J. Am. Soc. Clin. Oncol. 2013, 31, 2205-2218. [CrossRef] [PubMed]

205. Chung, A.S.; Kowanetz, M.; Wu, X.; Zhuang, G.; Ngu, H.; Finkle, D.; Komuves, L.; Peale, F.; Ferrara, N. Differential drug class-specific metastatic effects following treatment with a panel of angiogenesis inhibitors. J. Pathol. 2012, 227, 404-416. [CrossRef] [PubMed]

206. Colegio, O.R.; Chu, N.-Q.; Szabo, A.L.; Chu, T.; Rhebergen, A.M.; Jairam, V.; Cyrus, N.; Brokowski, C.E.; Eisenbarth, S.C.; Phillips, G.M.; et al. Functional polarization of tumour-associated macrophages by tumour-derived lactic acid. Nature 2014, 513, 559-563. [CrossRef] [PubMed]

207. Lorgis, V.; Maura, G.; Coppa, G.; Hassani, K.; Taillandier, L.; Chauffert, B.; Apetoh, L.; Ladoire, S.; Ghiringhelli, F. Relation between bevacizumab dose intensity and high-grade glioma survival: A retrospective study in two large cohorts. J. Neurooncol. 2012, 107, 351-358. [CrossRef] [PubMed]

208. Tolaney, S.M.; Boucher, Y.; Duda, D.G.; Martin, J.D.; Seano, G.; Ancukiewicz, M.; Barry, W.T.; Goel, S.; Lahdenrata, J.; Isakoff, S.J.; et al. Role of vascular density and normalization in response to neoadjuvant bevacizumab and chemotherapy in breast cancer patients. Proc. Natl. Acad. Sci. USA 2015, 112, 14325-14330. [CrossRef]

209. Gnoni, A.; Licchetta, A.; Memeo, R.; Argentiero, A.; Solimando, A.G.; Longo, V.; Delcuratolo, S.; Brunetti, O. Role of BRAF in Hepatocellular Carcinoma: A Rationale for Future Targeted Cancer Therapies. Medicina 2019, 55, 754. [CrossRef]

210. Krebs, M.; Solimando, A.G.; Kalogirou, C.; Marquardt, A.; Frank, T.; Sokolakis, I.; Hatzichristodoulou, G.; Kneitz, S.; Bargou, R.; Kübler, H.; et al. miR-221-3p Regulates VEGFR2 Expression in High-Risk Prostate Cancer and Represents an Escape Mechanism from Sunitinib In Vitro. J. Clin. Med. 2020, 9, 670. [CrossRef] 
211. Plebanek, M.P.; Angeloni, N.L.; Vinokour, E.; Li, J.; Henkin, A.; Martinez-Marin, D.; Filleur, S.; Bhowmick, R.; Henkin, J.; Miller, S.D.; et al. Pre-metastatic cancer exosomes induce immune surveillance by patrolling monocytes at the metastatic niche. Nat. Commun. 2017, 8, 1319. [CrossRef]

212. Lee, W.S.; Yang, H.; Chon, H.J.; Kim, C. Combination of anti-angiogenic therapy and immune checkpoint blockade normalizes vascular-immune crosstalk to potentiate cancer immunity. Exp. Mol. Med. 2020, 52, 1475-1485. [CrossRef]

213. Makker, V.; Rasco, D.; Vogelzang, N.J.; Brose, M.S.; Cohn, A.L.; Mier, J.; Di Simone, C.; Hyman, D.M.; Stepan, D.E.; Dutcus, C.E.; et al. Lenvatinib plus pembrolizumab in patients with advanced endometrial cancer: An interim analysis of a multicentre, open-label, single-arm, phase 2 trial. Lancet Oncol. 2019, 20, 711-718. [CrossRef]

Publisher's Note: MDPI stays neutral with regard to jurisdictional claims in published maps and institutional affiliations.

(C) 2020 by the authors. Licensee MDPI, Basel, Switzerland. This article is an open access article distributed under the terms and conditions of the Creative Commons Attribution (CC BY) license (http://creativecommons.org/licenses/by/4.0/). 